


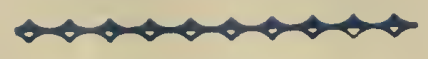

\section{Please}

handle this volume with care.

The University of Connecticut Libraries, Storrs 


\section{Digitized by the Internet Archive in 2012 with funding from \\ LYRASIS Members and Sloan Foundation}





\title{
THE PLIOCENE VERDI FLORA OF WESTERN NEVADA
}

\author{
BY \\ DANIEL I. AXELROD
}

UNIVERSITY OF CALIFORNIA PUBLICATIONS IN GEOLOGICAL SCIENCES Volume 34, No. 2, pp. 91-160, plates 13-23, 2 figures in text, 1 map in pocket

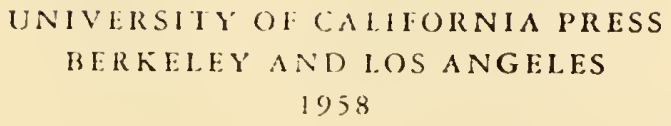





\title{
THE PLIOGENE VERDI FLORA OF WESTERN NEVADA
}

BY

DANIEL I. AXELROD

\author{
UNIVERSITY OF CALIFORNIA PRESS \\ BERKELEY AND LOS ANGELES \\ 1958
}


Volume 34, No. 2, pp. 91-160, plates 13-23, 2 figures in text, 1 map in pocket Submitted by editors January 7, 1958

lssued December 23, 1958

Price, $\$ 2.00$

\author{
University of California Press \\ BERKELEY AND LOS ANGELES \\ California \\ Cambridge University Press \\ LONDON, ENGLAND
}




\section{CONTENTS}

Abstract

Introduction

Previous work

Present environment . . . . . . . . . . . . . . . . . . . 92

Acknowledgments . . . . . . . . . . . . . . . . 95

Geology . . . . . . . . . . . . . . . . . . 95

Stratigraphy . . . . . . . . . . . . . . 95

Basement rocks . . . . . . . . . . . . . . . . . . 95

Alta andesite . . . . . . . . . . . . . . . . . 96

Kate Peak andesite . . . . . . . . . . . . . . . . . . 97

Coal Valley formation . . . . . . . . . . . . . . . . . 97

Post-Coal Valley rocks . . . . . . . . . . . . . . . . 105

Structure . . . . . . . . . . . . . . 105

Summary . . . . . . . . . . . . . . . . 106

Composition of the Flora . . . . . . . . . . . . . . . . . . 107

Paleoecology . . . . . . . . . . . . . . . . . . . . . . 111

Summary . . . . . . . . . . . . . . . . . . 117

Age . . . . . . . . . . . . . . . . . . . . 118

Stratigraphic evidence . . . . . . . . . . . . . . . . . . 118

Paleontologic evidence . . . . . . . . . . . . . . . . . . 118

Plants . . . . . . . . . . . . . . . . . . 118

Mammals . . . . . . . . . . . . . . . . . 125

Systematic Descriptions . . . . . . . . . . . . . . . . 125

Literature Cited . . . . . . . . . . . . . . . . . . . 134

MAP

1. Geology of a part of the Verdi basin

\section{FIGURES}

1. Geographic occurrence of the Verdi and other Tertiary floras in the nearby region

2. Generalized stratigraphic diagram of the Verdi basin

\section{TABLES}

1. Quantitative representation of species in the Verdi flora . . . . . . 108

2. Relationships of Verdi species to living plants . . . . . . . . . . 109

3. Floristic composition of the Verdi flora . . . . . . . . . . . . 110

4. Distribution of living woody plants related to Verdi species . . . . . 111

5. Comparative climatic data for Verdi area and for regions where the Verdi flora finds most of its modern relatives . . . . . . 114

6. Distribution of Verdi species in other Tertiary floras . . . . . . . 120

7. Cliseral, geographic, and climatic relations of Tertiary vegetation in western Nevada 


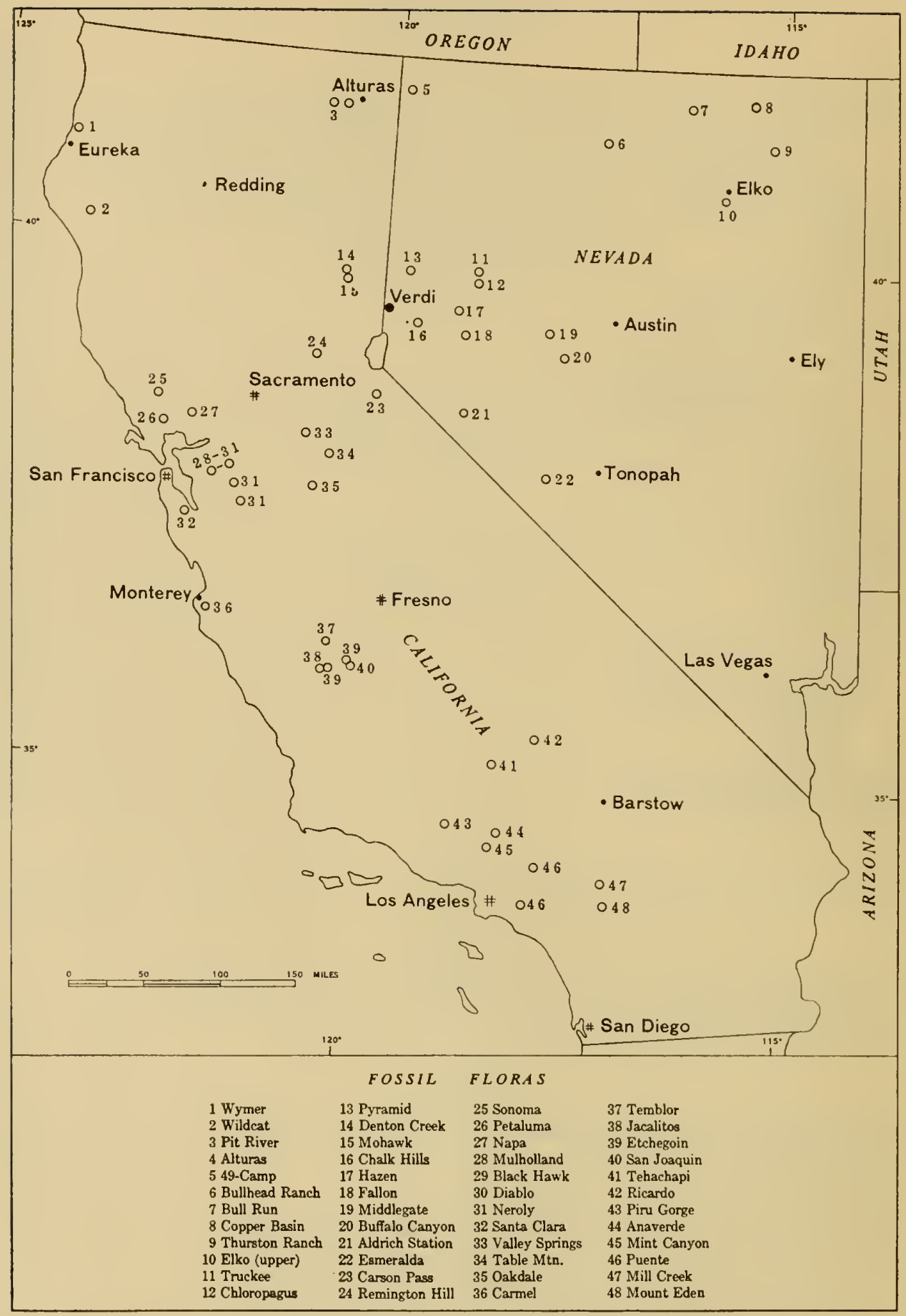

Fig. 1. Geographic occurrence of the Verdi and other Tertiary floras in the nearby region. 


\title{
THE PLIOCENE VERDI FLORA OF WESTERN NEVADA
}

BY

\author{
DANIEL I. AXELROD
}

\begin{abstract}
The Verdi flora of nineteen species is preserved in andesitic sandstones of the Coal Valley formation near Verdi, Nevada. The formation rests unconformably on Mio-Pliocene Kate Peak andesite on the south side of the basin, but on the north it lies on Oligocene Alta andesite or Jurassie granodiorite, the Kate Peak having been eroded there owing to uplift of the Peavine block by faulting following vulcanism. The Coal Valley rocks, which accumulated in a basin formed by downwarping and faulting, comprise (1) a lower, dark-colored, coarse conglomeratebreccia-sandstone member, (2) an olivine basalt, and (3) an upper, light-colored, sandstonepebble conglomerate-shale-diatomite member. The flora comes from near the middle of the upper member, and fragmentary mammalian fossils lie several hundred feet above and below it.

The plants are preserved in sediments that were deposited in the central floodplain area at an altitude of approximately 2,500 feet, and in a region of comparatively low relief. The flora resembles modern vegetation at the lower margin of yellow pine forest on the west slope of the Sierra Nevada and in southern California. Cottonwood and willow dominated the stream- and lake-borders on the Verdi floodplain. Nearby exposed slopes and well-drained flats supported an oak woodland and savanna, with chaparral present locally. A forest of pine and fir, with associates of manzanita, cherry, poplar, aspen, and willow lived chiefly in the bordering hills, extending locally into the lowlands on stream banks.

Verdi climate was subhumid, with yearly rainfall ranging from 18 to 20 inches in the lowlands, and increasing to 25 inches at the forest margin. Precipitation was distributed as winter rains and summer showers in contrast to the present winter rain and snow. Average January temperature was at least $10^{\circ} \mathrm{F}$. higher, and the frost-free season was fully two months longer than that at Verdi today.
\end{abstract}

The Middle Pliocene (Hemphillian) age of the flora is indicated by its geographic, climatic, and cliseral relations, a conclusion in larmony with the age implications of associated mammalian fossils.

\section{INTRODUCTION}

SEDIMENTS interbedded with the Tertiary voleanies in the central to northern part of the Sierra Nevada have yielded a number of fossil floras, distributed from near sea level in the western piedmont area to the summit of the range. From detailed paleoecological studies of these floras it has been possible to reconstruct the vegetation, climate, and topography of the region during much of the period. The evidence shows that lowland subtropical forests covered the range in the Early Tertiary, that mixed deciduous temperate forests dominated the low range in the middle of the period, and that semiarid woodland oceupied the flanks of the range and temperate forest the upper slopes of the lower barrier during the Late Tertiary. The pronounced zones of vegetation and climate that characterize the range today developed only at the close of the Cenozoic, at which time the massif was elevated to its present heights by warping and faulting (Axelrod, 1957a).

Parts of the Tertiary Sierran section also oceur to the east of the range in California and Nevada. Although fossil floras have been recovered from these rocks at several localities, they have not been analyzed up to the present time. Of these, the Pliocene Verdi and Chalk Hills floras, situated 8 miles west and 15 miles southeast 
of Reno, respectively, are of particular importance, for they occur in the Coal Valley formation, which is the eastern fluvio-lacustrine equivalent of the Mehrten formation that accumulated on the west Sierran piedmont. Analysis of these floras can go a long way toward filling a major gap which has existed in our knowledge of the Pliocene vegetation and climate to the lee of the range. This information will make it possible to compare contemporaneous floras on opposite sides of the range, and thus provide a basis for estimating the relative effectiveness of the Sierran ridge as a climatic barrier during the early and middle parts of the Pliocene. In addition, the floras shed considerable light on the evolution of the Sierran forest during the Late Teritary. Since the Verdi and Chalk Hills floras differ markedly in composition and in age, it seems best to consider them separately. We shall thus turn our attention first to the Verdi flora, and describe the Chalk Hills in a subsequent report.

\section{Previous Work}

The occurrence of fossil plants in the sediments near Verdi, a few miles west of Reno, was first noted during the survey of the Fortieth Parallel over three-quarters of a century ago (King, 1878, vol. 2, p. 849), but apparently no collections were made. Thirty years later, in his report on the geology and oil possibilities of the Reno region, Anderson (1909, p. 483) referred to a few plants in a small collection recovered "near Reno" which were identified for him by J. P. Smith, and considered Miocene. In the summer of 1914, H. S. Gale made a small but significant collection of the Verdi flora which is now in the U.S. National Museum. Apparently a formal report was never issued on this material, which includes three species that are not represented in the collections made subsequently at Verdi. F. H. Knowlton (in Mcrriam, 1916, p. 167) examined a small Verdi collection in the Museum of Paleontology, University of California, which was secured by John C. Merriam. He identified twelve species, of which six were considered to occur in the Esmeralda flora 150 miles southeast. Knowlton thought the Verdi was the same age as the Esmeralda flora, which was then regarded as Miocene.

The first large collection of the Verdi flora was made by Ralph W. Chaney in the early 'twenties. I added supplementary material to it in the summer of 1939, and again in 1947, 1953, 1954, and 1956. Since the more recent digging has not turned up any additional species, it is believed that a representative sample is now in hand. Although the flora is small, it nonetheless adds materially to our understanding of Late Tertiary environment in this region.

\section{Present Environment}

The Verdi locality is in the Truckee River valley 1 mile east of Verdi, at an elevation of 4,800 feet adjacent to the south bank of the Truckee River. The eastwest trending river valley is 2 to 3 miles wide, hemmed in by mountains on the north, south, and west. To northward is Peavine Mountain, whose summit lies at an altitude of 8,244 feet 5 miles distant. To southward, the valley is terminated by the north end of the Carson Range, a subsidiary block of the Sicrra Nevada whose rolling summit upland reaches 10,000 feet 7 miles distant. Crystal Peak ridge, 
one of the easterly scarps of the Sierra Nevada, towers 3,500 fect above the valley 3 miles west of the locality. As discussed below, the Truckee River valley in the Verdi area is a structural depression, formed by folding and faulting that have been in operation intermittently through most of Latc Cenozoic time.

The valley area lies in the transition from piñon-juniper woodland to the Sierran conifer forest. Scattered piñon (Pinus monophylla) and juniper (Juniperus utahensis) oceur just southeast of the fossil locality, and presumably were more abundant over the lowlands prior to clearing for agricultural purposes. The dominant shrub in the valley is Basin sage (Artemisia tridentata), associated with curl leaf mahogany (Cercocarpus ledifolius), rabbit brush (Chrysothamnus mauseosus), desert peach (Prunus andersonii), antelope brush (Purshia tridentata), plateau gooseberry (Ribes velutinum), and horsebrush (Tetradymia glabrata). With a slight rise in altitucle the Sierran forest quickly takes over as the dominant cover on the mountain slopes; it apparently was more abundant at lower levels, where it has been replaced by sage, before the extensive logging operations late in the last century. In this region the Sierran forest includes three major associations which replace one another with increasing elevation. The lower zone is dominated by Jeffrey pine (Pinus jeffreyi) and white fir (Abies concolor). Locally in protected canyons the common west-slope Sierran conifers, incense cedar (Libocedrus decurrens), sugar pine (Pinus lambertiana), and yellow pine (Pinus ponderosa), are also present. Common shrubs in the forest are green manzanita (Arctostaphylos patula), chinquipin (Castanopsis sempervirens), deer brush (Ceanothus integerrimus), white thorn (C. cordulatus), and bitter cherry (Prunus emarginata). Streamways support alder (Alnut tenuifolia), serviceberry (Amelanchier alnifolia), dogwood (Cormus californica), aspen (Populus tremuloides), black cottonwood (Populus trichocarpa), chokecherry (Prunus demissa), rose (Rosa gymnocarpa), and several species of willow (Salix spp.). The middle forest zone, which assumes dominance near 7,500 feet, is characterized by white fir (Abies concolor) and red fir (A. magnifica), with Jeffrey pine (Pinus jeffreyi) frequent on rocky sites. Common shrubs in this cooler, moister area include pine-mat manzanita (Arctostaphylos nevadensis), chinquipin (Castanopsis sempervirens), and huckleberry oak (Quercus vaccinifolia). Dense thickets of alder (Alnus tenuifolia) and bitter cherry (Prunus emarginata) choke the moister swales and flats, associated with lodgepole pine (Pinus contorta) and aspen (Populus tremuloides). The upper forest is a subalpine association, occurring chiefly above 8,500 feet. Among its dominants are white-bark pine (Pinus albicaulis), white pine (Pinus monticola), and mountain hemlock (Tsuga mertensiana). The higher mountain summits are largely barren to semibarren, and support an arcticalpine flora.

Present climatic conditions at the Verdi locality may be judged from the weather records at Reno, 8 miles east and 300 feet lower. From these data it is estimated that annual rainfall at the locality is approximately 12 inches, falling largely in the winter half of the year at which time it is accompanied by light snow. Average annual temperature is approximately $48^{\circ} \mathrm{F}$., with highest temperature about $102^{\circ} \mathrm{F}$. and the lowest extreme $-19^{\circ} \mathrm{F}$. The average maximum July temperature is estimated at $86^{\circ} \mathrm{F}$. and the average January minimum temperature is near 


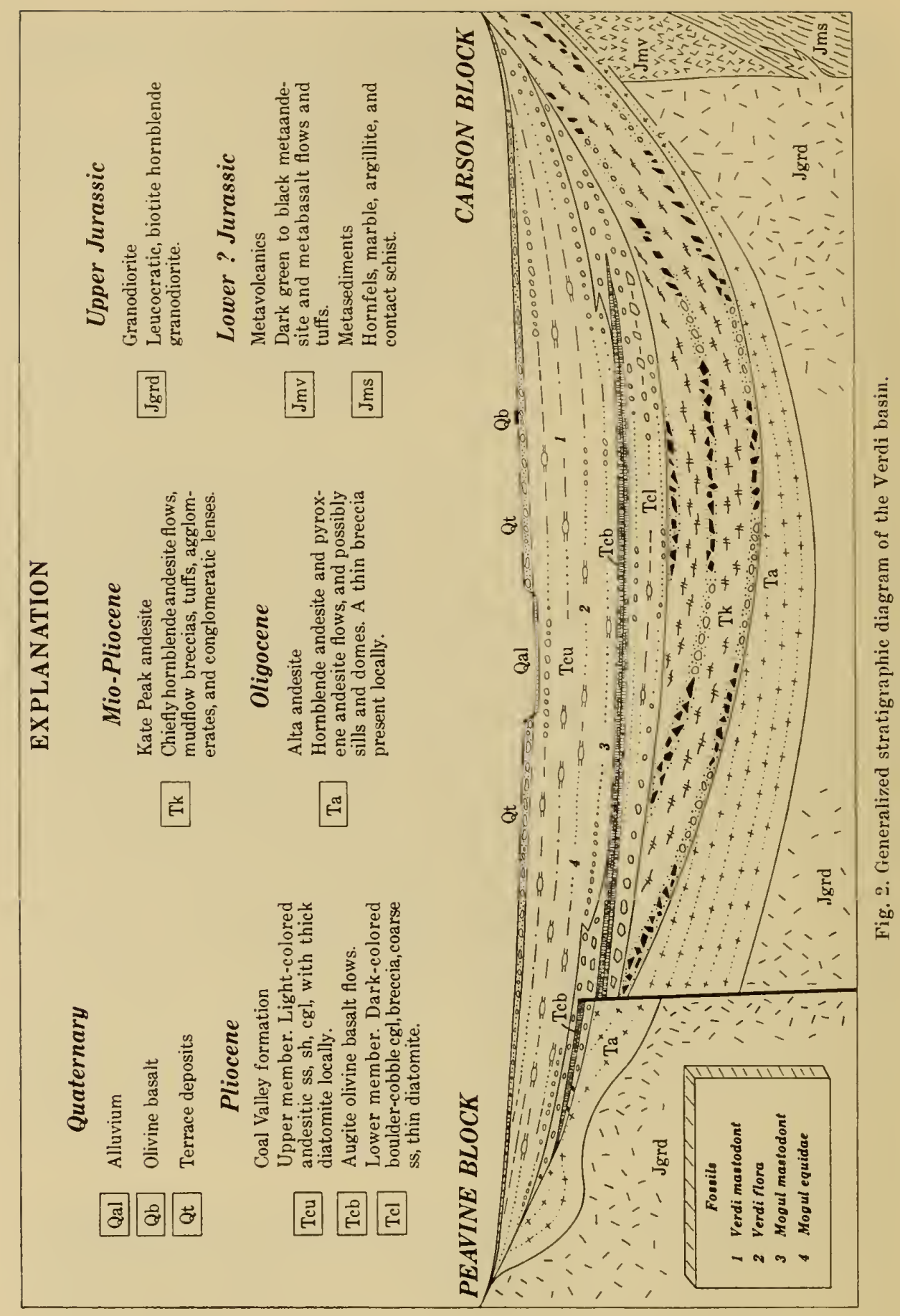


$19^{\circ} \mathrm{F}$. Thus the area is typified by a cold, semiarid, continental-type climate, with the hot summer days typically eloudless and with the cold winters bringing low temperature and light precipitation.

\section{ACKNOWLEDGMENTS}

The Carnegie Institution of Washington provided funds for ficld work to secure a large Verdi collection in the late spring of 1939. A preliminary report on the flora was assembled at the U.S. National Museum during tenure as National Research Fellow in 1939-1941, but completion of the study was interrupted by war. The Committee on Research, University of California, Los $\Lambda$ ngeles, granted funds to defray the cost of illustrating the fossils. The final part of the ficld work was carried out with a grant from the National Science Foundation as part of broad study of the Late Tertiary floras in western Nevada. For assistance in collecting I am indebted to my wife, Nancy, and to James F. Ashley and Robert E. Smith. Thanks are also due Roland W. Brown for permission to study the small but important Verdi collection in the U.S. National Museum, and for making available illustrations of three species in that collection which are not represented in the large suite of material in the Museum of Paleontology, University of California. Finally, thanks are extended to Cordell Durrell for help in the identification of the crystalline rocks, and to the Board of Editors in Geological Sciences for their sincere, eritical appraisal of the manuscript which has materially improved the paper.

\section{GEOLOGY}

Investigation of the geology of the Verdi area was undertaken chiefly to determine the position of the flora in the section, and to ascertain its stratigraphic relations to the fragmentary fossil mammalian remains which have been discovered in the area. No attempt was made to map the entire basin, because George A. Thompson has been mapping this and the adjacent region for the U.S. Geological Survey, and the project is nearly completed. Thus it will materially supplement the following brief observations which are based on a three-week field study in the vicinity of the fossil locality.

\section{STRATIGRAPHY}

BASEMENT ROCKS

The basement in this area comprises both metamorphic and granitic rocks. The oldest rocks are the metamorphics that crop out in the vicinity of Fleish, where they dip steeply. The lowest part of the section is made up of approximately 400 feet of metasediments including dark-gray hornfels, light-gray marble containing unidentifiable recrystallized marine invertebrates, lime-silicate garnet hornfels, quartz-feldspar-muscovite-andalusite schist, and associated veins of tourmalinized granodiorite which have invaded these rocks. The mctascdiments are overlain, apparently conformably, by 2,000 feet of black to dark greenish-black basic (andesite, basalt) metavolcanics which include both flows and tuffs. The metasediments and metavolcanies at Fleish appear to correspond to the rocks mapped by Lindgren (1897) on the adjacent Truckec quadrangle as Sailor Canyon formation and 
diabase, respectively; both formations are of presumed Lower Jurassic age. Similar rocks have been reported in the Virginia City area to the southeast (Thompson, 1956), and considered Triassic in age.

Light-gray, hornblende-biotite granodiorite representing part of the Sierran batholith of Late Jurassic age is exposed in three areas. On the hillside east of Fleish the sinuous contact between granodiorite and metavoleanics appears to be intrusive. The nearest metasediments, about 1,500 feet west of the contact, contain andalusite which is suggestive of contact metamorphism and hence tends to support the intrusive relation. In addition, the metasediments are intruded by granodiorite veins. The outcrops of granodiorite north of the river are similar to the rocks at Fleish, and presumably represent a part of the same pluton. There, both the Alta andesite and Coal Valley formation rest on it unconformably.

\section{ALTA ANDESITE}

At its type area in the Virginia City region 15 miles southwest (Gianella, 1936; Thompson, 1956), Alta andesite comprises a succession of pyroxene and hornblende andesite flows, tuff-breccias, possibly some contemporaneous intrusions, and a thin but prominent tuffaceous sand-shale-conglomerate unit, the Sutro member. The Alta section attains a maximum thickness of approximately 2,700 feet. Much of it has been altered hydrothermally, resulting in wide areas of bleached rocks. The Middle Oligocene age of the section is indicated by a rich flora that has been recovered from the Sutro member (Axelrod, 1949a).

Andesites similar in all respects to the Alta are exposed on the lower flanks of Peavine Mountain north of the Truckee River, where they rest on granodiorite. The section appears to be chiefly one of hornblende andesite and pyroxene andesite flows, but detailed mapping may demonstrate that sills and domes are represented. A thin, lenticular, andesite tuff-breccia is also present. The lavas range from dark gray-black to greenish-gray, gray-brown, and light gray in color. Plagioclase and hornblende phenocrysts are readily visible in most of the samples examined, though they are not clearly evident in some hand specimens, and locally some of the rocks contain hornblendes exceeding a centimeter in length. Parts of the section have been altered hydrothermally, especially near the larger faults where the rocks are commonly white to yellow, reddish and rust brown, with gossan often present on the contact. Not all of the alteration seems related to faulting, however; some of it away from the large faults may have been controlled by the complex joint system in the section.

The thickness and structure of the exposed section is not readily determinable because reliable attitudes are difficult to obtain in these highly jointed rocks. That important structures are present is clear from the relations in the upper part of Bull Ranch Creek, where a syncline is well exposed. Although no definite statement can be made as to the maximum thickness of the section, it almost certainly is in excess of 2,000 feet.

A much thinner section of the Alta andesite crops out on the north front of the Carson Range about 2 miles south of the area mapped, where it rests on metamorphic and granitic rocks. In general the $\Lambda$ lta has a much more patehy distribution than the Kate Peak, which unconformably overlies it. 


\section{KATE PEAK ANDESITE}

From its type area in the Silver City region 20 miles southeast (Gianella, 1936), Kate Peak andesite can be traced almost continuously into the Verdi basin, where it is exposed chiefly in the Carson Range south of the Truckee River. The scetion is largely one of interbedded agglomerates, mudflow brccias, and lavas. The agglomerate-breccia phase of the Kate Peak is readily recognizable from a distance, for it forms eraggy outcrops. The section is typically gray to gray-brown in weathered exposures, but fresh surfaces are light gray. The rocks are chiefly hornblende andesite in the area examined, with the breccia beds ranging from 10 or 20 feet, up to 50 or 60 feet thick. Cobble and boulder conglomerates which arc from 3 or 4 feet up to 20 or 30 fect thick, and characterized by reworked andesite, are scattered through the section. The pyroclastic phase increases in thickness to the southwest, and in the Truckee River canyon south of Fleish, near the California border, most of the section is composed of mudflow breccias and agglomerates. The lavas are light to medium dark gray, and characteristically porphyritic. They occur in units ranging up to several hundred feet thick, and are typified by several prominent joint systems that make it difficult to take reliable attitudes.

Along faults, hydrothermal alteration has locally affected parts of the formation. At several points near the marginal fault south of the river, as in sections 21 and 26, the section is quite bleached and shows up from the highway 2 to 3 miles distant as light yellow to orange and reddish outcrops. Since the overlying Coal Valley formation contains coarse to fine clasts derived from the bleached Kate Peak rocks, it is apparent that alteration occurred before the deposition of the Coal Valley formation, and that an unconformity separates them.

Kate Peak andesite rests on all the older rocks in this area. Near Fleish, it lies on granodiorite or on metamorphic rocks. To southward in the Carson Range, outside the mapped area, it rests on Alta andesite. Total thickness of the exposed section within the mapped area is in cxcess of 1,500 feet south of the river, and it rapidly increases to the south and west to over 2,500 feet. The formation lias generally only inoderate dips, ranging chiefly from $25^{\circ}$ to $40^{\circ}$, though near major faults it increases to $50^{\circ}$ or $60^{\circ}$, and locally to vertical.

On the basis of its interfingering relationships with the fossiliferous Mehrten formation of the Sierra Nevada, the Kate Peak andesites were erupted chiefly during a span of time ranging from the Mio-Pliocene transition (Early Clarendonian) to the later part of Early Pliocene time (Late Clarendonian), with a few spasmodic episodes extending into the early Middle Pliocene (Hemphillian).

\section{COAL VALLEY FORMATION}

\section{Areal Relations}

The sediments in the Verdi area were mapped first by King as part of the Truckee formation, and they have been considered to represent the Truckee by all subsequent investigators, including Louderback (1906), Anderson (1909), Buwalda (1914), Hill (1915), Merriam (1916), Stirton (1939), MacDonald (1950; 1956), and Thompson (1956). Nonetheless, my comparative studies of the Verdi sediments and the type Truckee formation, which lies 60 miles northeast, show that the 
Verdi rocks do not represent the Truckee as described by King. It is pertinent that King (1878, vol. 2, p. 849) originally noted that the Verdi beds are quite unlike the Truckee lithologically. They appeared on the Atlas of the Fortieth Parallel as Truckee chiefly because they are tilted to about the same degree, and were therefore thought to be of approximately the same age, and Truckee then being considered Miocene on the basis of limited fossil evidence (King, 1878, vol. 1, p. 423).

Not only are there marked difference between the Truckee formation and the sediments at Verdi which have previously been referred to the Truckee, but their relations to older rocks also differ greatly. The Truckee formation, as exposed over a wide area in the Carson Sink basin, includes three members: (1) a lower basalt breccia and tuff which grades upward into a sedimentary basalt breccia, coarse gritty sandstone, coquina, and a few thin beds of diatomite; (2) a thick, relatively pure diatomite section with numerous pumice beds and a few thin (2- to 3 -inch) sandstones; and (3) an upper flaggy limestone-pebble conglomerate-sandstone-thin diatomite member (Axelrod, 1956, p. 99). The type Truckee grades downward into siliceous shales of the Desert Peak formation, which in turn rests on basalt and biotite andesite of the Chloropagus formation. By contrast, the Verdi clastics are preponderantly andesitic, derived chiefly from erosion of the Oligocene Alta and the Mio-Pliocene Kate Peak andesite, on which the sediments rest unconformably. $\Lambda$ ssociated with the coarse conglomerates and sandstones in the lower part of the section are a few thin Kate Peak breccias; in the nearby area the Verdi sediments are interbedded with the upper part of the Kate Peak andesite. Since the fluviolacustrine Verdi section differs greatly from the Truckee, it must represent a different formation.

During my studies of the geologic occurrence of several Late Tertiary floras in western Nevada, sediments similar to those exposed near Verdi have been recognized over a wide region, extending from the Verdi area 75 miles southeastward to the middle drainage of the East Walker River, and 40 miles eastward to the margins of the Carson Sink. This fluvio-lacustrine section represents the Coal Valley formation, whose type area is at Coal Valley 4 miles south of Morgan's Ranch (Hawthorne Quadrangle), where the formation is 3,900 feet thick (Axelrod, 1956, p. 29). There, as elsewhere, the section is characterized by clasts derived from erosion of the Late Tertiary Sierran andesites. The section is typically fluviolacustrine, the andesitic sandstones and conglomerates alternating with tuffaceous shale, diatomite, soft lake clays, and locally with lignitic beds. Lenses of Kate Peak andesite are interbedded in its basal part at Coal Valley, and also at other localities in westcrn Nevada, as in the hills near Churchill north of Yerington, in the Desert Creek Range, and at Chalk Hills north of Virginia City. These conformable relations are not found in the Verdi basin because Kate Peak andesite was deformed in this area (and to the west) during the closing phases of vulcanism, resulting in the unconformable relation. Nonctheless, a few, thin hornblende andesite tuffs and breccias occur in the lower part of the section, showing that eruptions continued in the Verdi region into the early phases of Coal Valley deposition.

The Coal Valley is closely related to the Mehrten formation on the lower west slope of the Sierra Nevada. The chief difference is that the Coal Valley represents a fluvio-lacustrine section, whereas lake beds make up only a very minor part of 
the Mehrten, the bulk of which represents agglomerates and tuffs, as well as mudflow breccias, conglomerates, and coarse tuffaceous sandstones deposited by streams. Since they represent different environments-one largely fluvio-lacustrine, the other chiefly volcanic and fluvatile-it seems best to give them separato names. In connection with their close lithic relationship, it is pertinent that the formations are largely of the same age. The occurrence of Nannippus tehonensis in the basal beds at Coal Valley dates its lowest part as Early Clarcndonian (Stirton, 1939, p. 635; Axelrod, 1956, p. 33). The Mehrten formation on the west slope of the Sierra Nevada has Early Clarendonian faunas at Two-Mile Bar (Stirton and Goeriz, 1942), Goodwin Dam (Stirton and Goeriz, 1942), and Springfield Shaft (Merriam and Stock, 1933) ; all of them are at the base of the formation. The Table Mountain, 1944b) and Remington Hill (Condit, 1944a) floras of Early Clarendonian age also have a similar stratigraphic position in the formation on the west Sierran slope. The higher sections of the Coal Valley formation range into the Hemphillian, as judged from the Yerington fauna (Stirton, 1939, p. 637), which is in the Morgan Ranch formation just above the top of the Coal Valley formation (Axelrod, 1956, p. 67), and from the age indications of the Verdi flora as discussed below. The upper parts of the Mehrtell formation to the west also are Hemphillian, as shown by the Oakdale flora (Axelrod, 1944b) and fauna (Stirton and Goeriz, 1942).

Eastward, the Coal Valley interfingers with the Truckee formation. At many points along the west margin of the Carson Sink the Truckee contains thin sandstones and pebble beds derived from erosion of the Kate Peak andesite. Furthermore, old centers of Kate Peak eruption occur in several areas at the west margin of the Carson Sink. In the hills south of Fernley relatively complete sections of the Coal Valley and Truckee formations are interfingered. It is here that Kate Peak andesite rests on rhyolite tuff that appears to be equivalent to the Valley Springs formation which underlies the Mehrten formation on the west Sierran slope, and grades upward into the fluvio-lacustrine Coal Valley formation as characterized by andesitic pebble beds and sandstones. Thin basalt tuffs occur locally in this section, and increase rapidly both in frequence and in thickness a few miles eastward as the Coal Valley thins to a few pebbly sandstones and sandy shales in a typical Truckee section. It is apparent that the Truckee basin, which coincided largely with the present area of the Carson Sink, was being filled in part by streams carrying typical Kate Peak andesitic debris eastward from Sierran and other nearby centers of eruption.

\section{Litlology}

In the Verdi area, the Coal Valley formation commonly rests on an old soil that developed on volcanics or on basement rocks. The soft, uncompacted regolith ranges from 2 to 3 feet up to 8 or 10 feet thick in some areas. It is typically dark brown to chocolate, or locally black in color, and grades down into the underlying rocks. In some ways it resembles a dark prairie soil, but was not studied in detail.

For mapping purposes the overlying section was divided into two sedimentary members, separated generally by a basalt of discontinuous outcrop occurrence. Although the sedimentary units differ lithologically in their major features, similar 
rock types-such as andesite pebble conglomerate, coarse andesitic sandstone, and diatomite-oceur throughout. Owing to poor exposures in much of the area and to the numerous faults which bring different members-yet similar rocks-into juxtaposition, consistent separation of the units was found difficult.

Lower member.-Wherever the lower member is well exposed resting on the old regolith, it consists typically of poorly indurated, dark conglomerate and coarse sandstone made up largely of andesitic debris. On the north side of the basin the well-rounded clasts are reworked Alta andesite, but quartzite, gneiss, and granodiorite pebbles occur occasionally. The clasts are of variable size, depending chiefly on position with respect to the bordering valleys from which streams were carrying sediment into the basin. In general, they range from small to large cobbles, but boulders were noted locally. Coarse andesitic sandstones are associated with these conglomerates, and locally thin diatomaceous lenses a few inches to a foot or two thick occur in the section.

Dark-colored conglomerate of the lower member is well exposed on the flanks of the Carson Range south of the Truckee River, where it rests unconformably on Kate Peak andesite. Commencing in the area about 2 miles east of Fleish, the conglomerate is represented chiefly by small cobbles, but they rapidly increase in size to eastward. In sections 26 and 27 large cobbles and boulders up to a foot long are abundant. The clasts are largely Kate Peak andesite, but a few pebbles of Alta andesite as well as metamorphic and granitic clasts can be found in any large sample. The section alternates with coarse, gray to brown or (locally) yellowbrown thick sandstones, and thin tuffaceous sandy shales that are largely masked by the cobble-littered slopes. The conglomerate appears to have been deposited by comparatively large streams; locally the cobbles are somewhat flattened and display a crude imbricate structure. To eastward, in the valley of Hunter Creek, the conglomerate rapidly thins and grades laterally into finer lighter-colored sediments of the upper member which there rest on a thick regolith that is developed on Kate Peak andesite.

Sedimentary breccias are associated with the lower member in two areas. Along the irrigation canal adjacent to the Truckee River south of Lawton, a number of breccia beds are intercalated with thick, coarse sandstone and conglomerates. The most conspicuous breccia is $\mathbf{1 5 0}$ feet thick, but others below it range from 3 to 4 feet up to 10 or 12 feet thick. The breccias are monolithologic, consisting of angular blocks of Kate Peak lava, some of which are 6 to 8 feet long, embedded in a coarse matrix of Kate Peak debris. These breccias do not crop out in the hills to southward, probably because they represent mudflows that were deposited in the lowlands away from the bordering hills.

The thickest breccia section occurs north of the Truckee River from the mouth of Bull Ranch Creek westward into California, where it is terminated by a major north-south fault just off the map. The clasts are angular to subangular, and range in size from 1 or 2 feet up to block 5 feet long, all of which are in a poorly bedded, poorly indurated matrix of Alta andesite debris. In the lower part of the section on the Dry Creek road just north of Crystal Peak cemetery, blocks of granodiorite are also in the basal part of the section, which here rests unconformably on Kate Peak mudflow-breccia. The breccia has a maximum thickness of approximately 300 
feet, and grades upward into large cobble conglomerates of the lower member which overlap Alta andesite north of the basin fault against which the breceia is buttressed.

Basalt member.-In most of the area where it is exposed, basalt separates approximately the lower dark-colored member from the upper light-colored part of the formation, though in the northern part muel of it is in the lower member. In that area it is separated usually from Alta andesite by only a thin regolith or by a few feet of the lower member, but locally it may rest on the volcanies. It is not exposed in most of the Truckee River valley owing to structural complications. To judge from its relations along the Truckee River near Mogul, and in the low hills south of Lawton, it lies well above the base of the section in the valley area. This variable stratigraphic position is explainable on the basis of extravasation on the margins of the basin, as well as within the basin proper.

The thickest section crops out on the bluff bordering the Truckee River on Highway 40 a mile east of Verdi, where it is approximately 400 feet thick, and comprises three well-defined flows. The lowest one is buttressed against basalt agglomerate at the highway level; the second one lies on a lenticular 8- to 10-foot tuffaceous sand and gravel section; and the upper one rests on a thin, discontinuous tuffaceous sand. The lower flow is black, massive, exhibits columnar jointing, and is an augite olivine basalt. The upper augite olivine basalt flows are typically flow-jointed, reddish brown on weathered surfaces, but a fresh surface reveals a gray-brown color and a subvitreous surface. Louderback (1906, p. 669) interpreted this basalt as a Quaternary lava that had poured off the slopes of Peavine Mountain to northward. Actually, it has been gently folded, and is faulted. To the northeast it dips under the Coal Valley sandstones and conglomerates of the basal part of the upper member. The basalt appears to rest on Kate Peak andesite to judge from the relations near the middle of the basalt outerop a hundred yards north of the highway.

Basalt is much thinner elsewhere in the region. The numerous patches in the area to the northwest range from 10 to 30 feet thick. At the east margin of the map south of Lawton, the lower and upper flows are separated by 25 to 30 feet of sediment. The thick river bluff section presumably represents accumulation in a valley, as compared with the more widely distributed upper flow-jointed section that appears to have poured out over a low plain adjacent to, and within, the basin.

Upper member.-The dark-colored lower conglomerate-breccia member grades upward into a lighter, gray to brown section typified by coarse sandstone, pebble conglomerate, diatomite, and sandy shale. The elastics north of the river, having been derived from areas of bleached Alta rocks, are often varicolored, commonly mustard brown, yellow-brown, and occasionally rusty, as well as gray when derived from the less-altered section. The sandstones frequently show rapid changes in color, and are especially conspicuous as thinner beds from 1 to 3 or 4 feet thick. The succession of different-colored sandstones and pebble beds derived from Alta andesite is suggestive of flood deposits coming from relatively local drainage areas near at hand. A similar diversity of sediment could readily be derived from the different exposures of Alta andesite that crop out now in valleys on the slopes of Peavine Mountain. Summer showers in the drainage basins bordering the Verdi 
floodplain probably transported the relatively homogeneously colored sandy sediments into the lowlands. The beds show rapid lateral and vertical variation in texture, and are typified by sedimentary structures such as scour-and-fill, crossbedding, graded bedding, lenticularity, and numerous small discontinuities, all of which are regularly developed under conditions of flood deposition. The sediments are chiefly coarse and gritty, and poorly indurated. They are associated with soft, pebbly sandstones and pebble conglomerates, ranging from gray or brown to yellow-brown in color. In thickness they vary from a few inches up to beds 8 to 10 feet thick. Regularly associated with the sandstones alld conglomerates are soft, regolithic-like sediments that may well represent old soils that developed on the floodplain. Gray to brown tuffaceous shales, and creamy to white diatomaceous beds are conspicuous in the section.

South of the river, in the area near Fleish and eastward for over a mile, the lowest exposed beds represent a light-gray to tan section of coarse to fine sandstone, pebble conglomerate, and thin diatomite. A few thin andesite tuffs are represented in the section. Blue to blue-gray andesitic sandstones are prominent in the area, ranging from a few feet up to 10 or 15 feet thick, and they are regularly current marked. To the east this section overlies the prominent dark-colored conglomerate of the lower member. The gradational contact is generally marked by the disappearance of coarse conglomerate, and a change in color from dark gray and dark brown to light gray, tan, and locally white. The white beds are lenses of diatomite which are common in the section. Although they are comparatively abundant, they are generally thin, ranging from a few inches to a few feet thick, and commonly lenticular.

The higher parts of the Coal Valley formation are typified by light-colored, fluvio-lacustrine sediments in which diatomite is prominent. Within the mapped area diatomite ranges up to 30 or 40 feet thick or more, associated regularly with poorly indurated gray to blue-gray andesitic sandstones and pebble beds. To the east, outside the limits of the area, diatomite makes up an even more prominent part of the section. At Chalk Bluffs, on the north side of the Truckee River just east of Lawton, it is fully 500 feet thick and extends to the nortl and south where it overlaps the older voleanics on the front Peavine Mountain and the Carson Range. Apparently the same section occurs also at the base of Crystal Peak ridge west of Verdi, in California.

Locally the diatomaceous beds are tuffaceous, and north of Mogul they are associated with rhyolite tuff. The center of eruption of this tuff may have been in the area to eastward, for in the lower drainage of Long Valley Creek in the northern part of the Virginia City Quadrangle 15 miles east, there are rhyolite centers which contributed pumiceous tuffs to the upper part of the formation there (Thompson, 1956, p. 56).

The clastics associated with the higher parts of the upper member include poorly indurated, blue to blue-gray, coarse- to fine-grained sandstone and sandy shales. Locally, however, there are interbeds of yellowish-brown or orange sandstones derived from the altered voleanic sections that border the basin. In general, the clastics occur in beds ranging from a few inches to several feet thick. Like the rest of the section, they regularly show numerous cross-beds and other current 
markings typical of floodplain deposition. The conglomerates are in general lighter colored than those lower in the section. The clasts are similar, but their small size and the more abundant matrix of sand gives the rock an over-all lighter color. The volcanic pebbles are generally small, though sinall cobbles are present locally.

\section{Topographic Setting}

The Coal Valley formation was depositcd in a structural low, which apparcntly was brought into existence by downwarping of the Carson block, and by rencwed faulting on the front of the Peavine block following erosion of the Kate Peak andesite there (see "Structure"; also fig. 2). The bordering scarp on the north side of the basin appears to have been low to judgc from the few exposures available for study. The bulk of the formation accumulated on a floodplain within the basin, but owing to continued subsidence the successive members gradually overlapped the marginal fault and bordering low slopes.

Higher hills appear to have stood to the northwest and southeast of the plant locality only during the early phases of deposition. On the north side of the basin coarse clastics are found near Bull Ranch Creek, where a 300-foot breccia is buttressed against Alta andesite along a fault that appears to mark the old scarp. The occurrence of granodiorite blocks in the section suggests that they probably were derived from a region of moderate relief directly north of the scarp, scveral miles northwest of the plant locality. On the south side of the basin higher hills were present in the area southwest of Hunter Creek, for the coarsest conglomerates occur there. The deposits derived from these higher areas are, however, at stratigraphic levels well below the Verdi flora. By the time the flora was living, bordering hills were much lower, to judge the finer nature of the marginal deposits. Thus there is no reason to suppose that high mountains were in the immediate area during deposition of the sediments containing the Verdi flora; the hills flanking the basin may have been only a few hundred feet above the Verdi floodplain. Since the extravasation of Kate Peak andesite just prior to the Coal Valley deposition was chiefly by autobrecciation from fissures, rather than by eruptions (Curtis, 1954), high volcanic mountains probably were not in the immediate region. Nonetheless, the presence of occasional andesite lapilli tuff in the Coal Valley section suggests that a few low cones may have dotted the distant hills.

The existence of coaly beds in the section, the presence of diatomaceous lenses at most stratigraphic levels, and the occurrence of shaly beds filled with aquatic plants, clearly indicate ponded water bodies in the lowlands. Most of these beds are thin and generally discontinuous, suggesting more or less short-lived, small lakes, ponds, and swamps. Since they occur all across the basin, and at nearly all stratigraphic levels, generally low relief on the floodplain is suggested. Deposition in these sites was regularly brought to a close by flooding and filling up of these small basins by coarse sands and gravels deposited chiefly at times of flood, as judged from conspicuous cross-bedding, scour and fill, and other structures in the sediments. Finally, it is recalled that the upper, flow-jointed basalt, which occurs below the flora stratigraphically, has a comparatively wide distribution in the area. This also suggests a subdued lowland, for it is doubtful if such a thin flow would spread very widely if moderate relief were present. 
Fossils

All of the fossils recovered in the Verdi basin occur in the upper sandstoneconglomerate member. Owing to extensive alluvial and terrace cover in the lowlands where they occur, and to numerous faults, mappable beds suitable for detailed stratigraphic correlation were not found. For this reason the following comments on the stratigraphic occurrences of the fossils are generalized.

Plants.-The Verdi flora was collected from blue-gray sandstones exposed in a railroad cut on the Southern Pacific Railroad at U.C. Mus. Pal. Locality 102. The site is near the southern margin of section 9, just south of the Truckee River a mile east of Verdi where the Old Verdi Road crosses the first railroad overpass (there are two) south of the river. The plants occur in sandstones exposed in the northfacing railroad cut, extending from the bridge westward for about 150 feet to where the exposure is covered by a clump of chokecherry; and best fossils were secured from the fine-grained sandstones at the west end of the cut. The 28-foot section exposed here is one of coarse, cross-bedded, lenticular andesitic sandstones interbedded with thin diatomaceous lenses and sandy shales, as shown in figure 2 on plate 14. At this locality the section is dipping $2^{\circ}$ to $3^{\circ}$ northwest. About 300 yards farther west, across a north-south fault, the dip increases to about $15^{\circ}$. There the section includes thick diatomite along with sandstone, shale, and pebble conglomerate. As nearly as can be judged, the Verdi flora is approximately 1,000 to 1,200 feet above the basalt, though it may be less if the river-bluff section along which the section was measured is duplicated by faulting.

Mammals.-Identifiable mammalian remains have been found at three localities in the Verdi basin; their stratigraphic occurrence is outlined here and their age significance is reviewed in the chapter on age.

1. The mastodont tooth described by Buwalda (1914) comes from a locality "about three-fourths of a mile southeast of Verdi." Although the exact site can not be pinpointed, the rocks in the area referred to form a northwesterly dipping section of coarse, blue-gray andesitic sandstone, small-pebble conglomerate, sandy shale, and thick diatomite. This part of the section is typical of the middle to upper part of the upper member. As nearly as can be determined, the locality is at least 400 to 500 feet above the flora stratigraphically.

2. A second mastodont tooth, now at the University of Nevada, was discovered in exposures close to Mogul. This site is clearly in the lower part of the upper member, in yellow-brown Alta-derived coarse sandstones and pebble conglomerates which dip $10^{\circ}$ east. According to my observations, it is approximately 400 feet above the basalt, and approximately 600 feet below the flora stratigraphically.

3. A fragmentary specimen of a Hipparion tooth was collected by Ira LaRivers, of the University of Nevada, at a locality 1 mile north of Mogul, in a section of alternating sandstone, pebble conglomerate, sandy shale, and diatomite. It lies approximately 200 feet above the Mogul mastodont, and about 400 feet below the flora. 


\section{POST-COAL VALLEY ROCKS}

The rocks that accumulate in the region following deposition of the Coal Valley formation comprise terrace deposits and basalt. Several terraces arc in the Truckee River valley, and some of them lie 800 feet above the present river. The higher ones are covered with Kate Peak debris on the south side of the basim, but Alta andesite on the north. The deposits range from 10 or 15 feet up to 30 or 40 feet thick. These older terrace deposits can be traced onto the bordering slopes of Peavine Mountain and the Carson Range north and south of the river, where they merge into old erosion surfaces. The material making up the low terrace deposits near the Truckee River differs from that on the high terraces in one important respect: granitic and metamorphic clasts oceur in abundance only on the low terraces. This clearly indicates that the exposure of wide areas of basement rock in the nearby region to westward is a comparatively recent event. Since many of the contacts between the present broad exposure of the basement and younger rocks are faults, the inference is that they are quite recent, probably very late Pleistocene.

Dark-gray to black basalt that weathers reddish-brown, and on fresh fracture reveals a dull vitreous surface, is present on the high terrace and bordering erosion surface south of the Truckee River in section 21. V. P. Gianella has suggested that it may be equivalent to the Lousetown andesite-basalt that covers a wide area in the Carson Range to southward. Similar rocks appear to have been mapped by Lindgren (1897) over a broad region in the Truckee quadrangle to the southwest. At several localities in the area north and northwest of the basalt bluff near the flora, basalt has intruded and baked the Coal Valley diatomite brick red (Gianella, 1948). It may be a part of the same magma that contributed to the flows on the high terrace south of the river; in any event, it is of post-Coal Valley age.

\section{STRUCTURE}

The regional relations of the Coal Valley-Kate Peak unconformity have an important bearing on interpreting the structure of the Verdi basin. In the area to the east, near Virginia City, the Coal Valley formation is interbedded with the higher parts of the Kate Peak andesite (Gianella, 1930; Thompson, 1956). ${ }^{1}$ In the Verdi basin the Coal Valley rests with angular discordance on the volcanics; although the lower parts of the formation locally contain a few thin Kate Peak tuffs, they appear to represent the last phases of that voleanic episode. In the region near Boca, 10 miles southeast, Daley and Poole (1949) found an angular discordance of $15^{\circ}$ to $20^{\circ}$ between the Kate Peak andesite and the Coal Valley sediments. It is apparent that in proceeding eastward from the tectonically active Sierra Nevada, the angular unconformity between the Coal Valley and Kate Peak andesite disappears in the conformable section.

The unconformity apparently was owing both to folding and faulting. Discordance between the Coal Valley formation and the underlying volcanies shows that warping followed Kate Peak vulcanism. Furthermore, since younger sediments lap onto the Kate Peak and Alta andesites in proceeding farther east, it is

\footnotetext{
1 These sediments were mapped as the Truckee formation by Thompson.
} 
apparent that downwarping was greater in the western sector, nearer the Sierra Nevada. It was also in this region that the marginal east-west faults appear to have been more active during deposition, and there has apparently been renewed movement on them. As previously noted, a coarse sedimentary breccia is buttressed against an old scarp in the area from Bull Ranch Creek westward into California. To northward, the fault is clearly overlapped by younger sediments. Movement continued into the early part of Coal Valley deposition because subangular blocks of Coal Valley basalt occur in the lower member at the mouth of Bull Ranch Creek, and also at the northwest corner of the prominent river-bluff section. More recent movement on this fault is obviously indicated, for it brings the upper and lower members into juxtaposition.

One of the puzzling features of the geology of the area is that Kate Peak andesite is not exposed on the flanks of Peavine Mountain, yet the thick section in the Carson Range dips northward toward it. One might argue that the Peavine block was an elevated tract and that the Kate Peak did not accumulate there. This seems unlikely, however, because Kate Peak andesite occurs north of the river at three sites (map 1), and in each instance it is separated from Alta andesite by a major fault. Furthermore, a thick Kate Peak section is exposed along the west margin of Peavine Mountain in the valley of Dry Creek on the California-Nevada border. These relations suggest that Kate Peak andesite probably covered at least parts of the Peavine block, that during the late phases of Kate Peak eruption the Peavine block was elevated by faulting, following which Kate Peak andesite was eroded from the area. The fault presumably corresponds to the one directly north of Verdi against which the 300 -foot breccia rests, and on which renewed movement accounts for the basalt-bearing breccia beds early in Coal Valley deposition.

Aside from the major northwesterly trending fault that was active early in deposition, there are two younger sets. As shown on the map, a northwesterly trending set slices the basin into a prominent pattern. Locally, it is cut by a northerly to northeasterly trending set that is more prominently developed to the west, in California.

\section{Summary}

1. The Coal Valley formation, which contains the Verdi flora and mammalian fossils, rests unconformably on Kate Peak andesite or on metavolcanics on the south side of the basin, but on Alta andesite or granodiorite to northward.

2. The structural setting of the basin appears to have been a downwarp bordered by a low fault scarp on the north which was active in the early phases of deposition, but was soon overlapped by the accumulating sediments (fig. 2).

3. The section is approximately 3,000 feet thick and contains three mappable units, all of which may rest on an old regolith on the margins of the basin: (1) a lower, dark-colored conglomerate-breccia-sandstone member, (2) an augite olivine basalt, and (3) an upper, light-colored, pebble conglomerate-sandstone-shalediatomite member. The flora is near the middle of the upper member, and mammalian fossils lie several hundred feet above and below it.

4. The presence of hydrothermally altered Kate Peak andesite cobbles in the Coal Valley formation indicates metasomatism occurred before deposition of the 
Coal Valley rocks. Judging from the evidence of age, as discussed below, alteration probably took place near the transition from Early to Middle Pliocenc time.

5 . The northwesterly trending basin fault appear's to have been active in the Lower and Middle Pliocene, and more recently as well. The prominent northwesterly trending set may be as old as Late Pliocene to Early Pleistocene, but the younger northeasterly trending set may be Late Pleistocene.

\section{COMPOSITION OF THE FLORA}

The Verdi flora is now known to include 19 species, distributed among 12 genera and 10 families. Three of the plants are herbaceous aquatics, including a thallophyte (Chara), a monocotyledon (Potamogeton), and a dicotyledon (Nymphaeites). The remaining 16 are woody, comprising 4 conifers and 12 dicotyledons.

Systematic List of Speeies

Characeae

Chara verdiana new species

Pinaceae

Abies concoloroides Brown

Pinus florissanti Lesquereux

Pinus prelambertiana new species

Pinus pretuberculata Axelrod

Naiadaceae

Potamogeton verdiana new species

Salicaceae

Populus alexanderi Dorf

Populus pliotremuloides Axelrod

Populus subwashoensis Axelrod

Salix boisiensis Smith

Salix truckeana Chaney
Fagaceae

Quercus prelobata Condit

Quercus renoana ncw species

Quercus wislizenoides Axelrod

Nymphaeaceae

Nymphaeites nevadensis (Knowlton) Brown

Grossulariaceae

Ribes galeana new species

Rosaceae

Prunus moragensis Axelrod

Rhamnaceae

Ceanothus precuneatus Axelrod

Ericaceae

Aretostaphylos verdiana new species

The fossils are represented chiefly by leaf impressions, though conifer needles, cones, and cone-scales form an important part of the record. Judging from the relative abundance of the Verdi specimens, as shown in table 1, leaves of the common Pliocene cottonwood Populus alexanderi account for over 90 per cent of the material. If we add to this figure the data for the other common riparian species, aspen (Populus pliotremuloidcs) and willow (Salix truckeana), streamborder plants comprise 95 per cent of the collection. It is apparent that species representing forest and woodland vegetation are subordinate in the Verdi flora.

The table 1 shows that aside from the dominant cottonwood, three of the conifers, Abies concoloroides, Pinus florissanti, and $P$. pretuberculata are rather common in the flora. In the absence of other evidence, one might suppose that they were living as close to the site of deposition as the species of cottonwood, aspen, and willow, which have a generally similar quantitative record. If these forest trees had lived in moderate numbers near the Verdi site, their usual forest associates should also have a fair representation in the flora; however, all of them are quite rare. Furthermore, many of the common species in related living forests are not now known to have fossil equivalents in the flora. They might well be expected there if forests had occupied sites near at hand.

The mode of occurrence of the conifers in the Verdi sediments gives a clue to 
their probable distribution in the region. The pine cones and fir seales occur chiefly in the coarser sandstones, associated usually with carbonaceous layers. It was also in these local concentrations of plant debris that the majority of the pine and fir needles were found. In addition, the coarser sands, which contain most of the re-

\section{TABLE 1}

Quantitative Representation of Species in the Verdi Flora (Unless otherwise indicated, all records represent leaf impressions)

\begin{tabular}{|c|c|c|}
\hline Fossil species & $\begin{array}{l}\text { Number of } \\
\text { specimens }\end{array}$ & Per cent \\
\hline Populus alexanderi...... & 1,987 & 92.1 \\
\hline Populus pliotremuloides . ..................... & 47 & 2.2 \\
\hline $\begin{array}{l}\text { Abies concoloroides } \ldots \ldots \ldots \ldots \ldots \ldots \ldots \ldots \ldots \ldots \ldots \ldots \ldots \\
\text { needles: } 28 \\
\text { cone-scales: } 6\end{array}$ & 34 & 1.6 \\
\hline 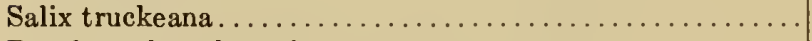 & 25 & 1.2 \\
\hline Populus subwashoensis . ....................... & 15 & 0.7 \\
\hline 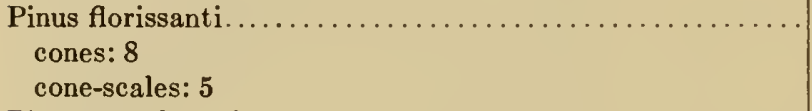 & 13 & 0.6 \\
\hline $\begin{array}{l}\text { Pinus pretuberculata. } \\
\text { cones: } 3 \\
\text { fascicles: } 10\end{array}$ & 13 & 0.6 \\
\hline $\begin{array}{l}\text { Pinus prelambertiana } \ldots \ldots \ldots \ldots \ldots \ldots \ldots \ldots \ldots \ldots \ldots \ldots, \ldots \\
\text { cones: } 1 \\
\text { fascicles: } 3\end{array}$ & 4 & 0.2 \\
\hline $\begin{array}{l}\text { Prunus moragensis } \ldots \ldots \ldots \ldots \ldots \ldots \ldots \ldots \ldots \ldots \ldots \ldots \ldots \ldots \\
\text { leaves: } 3 \\
\text { seeds: } 1\end{array}$ & 4 & 0.2 \\
\hline Quercus renoana. $\ldots \ldots \ldots \ldots \ldots \ldots \ldots \ldots \ldots \ldots \ldots \ldots \ldots \ldots \ldots \ldots$ & 3 & 0.1 \\
\hline 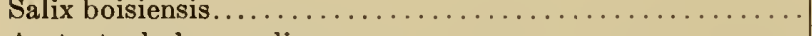 & 3 & 0.1 \\
\hline Arctostaphylos verdiana $\ldots \ldots \ldots \ldots \ldots \ldots \ldots \ldots \ldots \ldots \ldots \ldots$ & 2 & 0.2 \\
\hline Quercus wislizenoides......................... & 2 & 8.0 \\
\hline 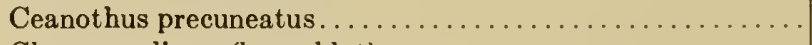 & 1 & \\
\hline 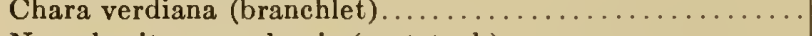 & 1 & \\
\hline 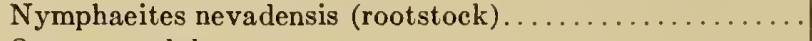 & 1 & 0.2 \\
\hline 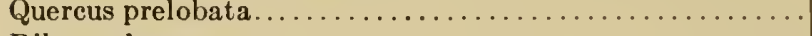 & 1 & \\
\hline 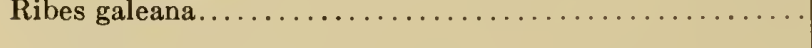 & 1 & \\
\hline 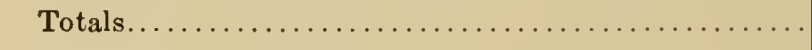 & 2,157 & 100.0 \\
\hline
\end{tabular}

mains of forest trees and shrubs, are typically cross-bedded, and show current marks, graded bedding, and scour-and-fill structures. By contrast, the finer sandstones in which the dominants of the flora are preserved display the features of more nearly quiet-water deposition. The coarser sandstones intercalated in this section thus appear to represent flood deposits. On this basis, the needles and cones, together with the associated carbonaceous layers, are interpreted as debris carried into the lowlands from valleys bordering the basin at times of high water. Similar concentrations of drifted material can be seen today along floodplains, and at the foot of fans flanking mountainous areas. The suggestion that the Verdi 
forest lived chiefly on bordering slopes and in adjacent valleys would not preelude the occurrence of a few forest trees scattered on the floodplain, in much the same way that pines now straggle down the Truckee River valley to the vicinity of the Verdi locality.

As mentioned in the discussion of the geologic occurrence, thinly laminated, impure diatomaceous lenses, ranging from 3 or 4 inches, up to 10 or 12 inches

TABLE 2

Relationships of the Verdi Species to Living Plants

Similar living plants

TREES

Abies concoloroides............................. concolor (Gordon) Parry

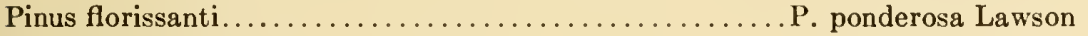

Pinus prelambertiana ......................... lambertiana Douglas

Pinus pretuberculata........................ attenuata Lemmon

Populus alexanderi............................. trichocarpa Torrey and Gray

Populus pliotremuloides....................... tremuloides Michaux

Populus subwashoensis......................... tremula davidiana Schneider

Quercus prelobata......................... lobata Nees

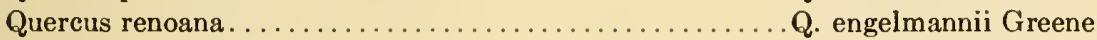

Quercus wislizenoides...................... wislizenii DeCandolle

SHRUBS

Arctostaphylos verdiana...................... nevadensis Gray

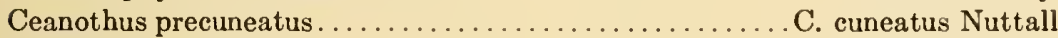

Prunus moragensis ........................... emarginata (Douglas) Walpers

Ribes galeana.............................. roezlii Regel; other spp.

Salix boisiensis.......................... scouleriana Barratt

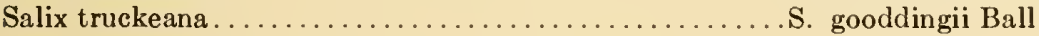

HERBS

Chara verdiana ............................. spp.

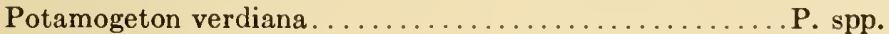

Nymphaeites nevadensis . . . . . . . . . . . . . . Nymphaea spp.

thick, are interbedded with the sandstones and sandy shales at the Verdi locality. These diatomaceous beds apparently accumulated in ponds and shallow lakes on the Verdi floodplain. Many of these layers are densely matted with scores of slender leaves of the pondweed, Potamogeton verdiana. They are so abundant, and the plant represents such a specialized environment, that it has seemed best not to include it in the leaf count (table 1 ).

All the foliar and reproductive structures comprising the Verdi record are so similar to those produced by living plants there is little doubt that the fossils are close relatives of modern species. The living plants that appear to be most similar to the fossils are listed in table 2, in which the species are grouped according to their usual growth form or habit. As judged from these data, the flora includes 10 trees, 6 shrubs, and 3 herbs. 
From a floristic standpoint, table 3 shows that the flora contains members of two Tertiary Geofloras. The Arcto-Tertiary Geoflora, of holaretic origin, was dominated by conifers and deciduous hardwoods that are represented now by elosely similar species in the temperate parts of holaretica. Most of the Verdi plants are members of its West American Element, which includes those fossil species that resesmble plants eharacterizing the conifer forests in the far West. The Verdi species are chiefly members of its Sierra-Caseade Component, which are similar to trees and shrubs in the forests of the Sierra Nevada and Caseades. Only one speeies in the flora, Populus subwashoensis, does not have a close relative in

\section{TABLE 3}

Floristic Composition of the Verdi Flora

(Asterisk indicates species occurring in more than one floral element)

\begin{tabular}{c|c}
\hline ARCTO-TERTiarY Georlora & MADRO-TERTiarY GeOFLoRA \\
\hline West American Element & California Woodland Element \\
Sierra-Cascade Component & ${ }^{*}$ Ceanothus precuneatus \\
Abies concoloroides & Pinus pretuberculata \\
Pinus florissanti & Quercus prelobata \\
Pinus prelambertiana & Quercus renoana \\
Populus alexanderi & Quercus wislizenoides \\
Populus pliotremuloides & Salix truckeana \\
Ribes galeana & California Chaparral Element \\
Prunus moragensis & ${ }^{*}$ Ceanothus precuneatus \\
Salix boisiensis & \\
East Asian Element & \\
Populus subwashoensis & \\
\hline
\end{tabular}

the far West. It is a relict of the East Asian and East American Elements, which included deciduous hardwoods and conifers such as beech, elm, hickory, Chinese redwood, water cypress, swamp cypress, katsura, hornbeam, and others that find their nearest living relatives in the summer-wet, eastern parts of the northern continents. Although they dominated the Areto-Tertiary Geoflora in this region well into the Miocene, commencing at the close of that epoch and continuing through the Pliocene, they were supplanted gradually by species of the West American Element as summer rains were reduced in frequency and in amount.

The Madro-Teriary Geoflora comprises the semiarid woodland and chaparral vegetation that had appeared over the drier parts of southwestern North America by the end of the Early Tertiary, and gradually spread over the western part of the continent as dry elimate expanded during the middle and later parts of the period. It is represented in the Verdi flora chiefly by members of the California Woodland Element, which resemble plants in the present oak woodland communities of California. The species of buckbrush (Ceanothus) oecurs not only as a shrub scattered in the woodland, but also forms an important part of the chaparral that borders oak woodland and forest vegetation in California. Plants representing the Sierra Madrean Woodland Element, which are similar to living trees and 
shrubs in the summer-wet sections of southwestern North Amcrica, are not now known in the Verdi flora.

Summarizing, it is apparent that the Verdi flora is dominated by riparian-and lake-border vegetation, that conifer forest had only a restricted occurrence in the lowlands, and that oak woodland also was rare at the site of deposition. The Verdi species, representing both the $\Lambda$ reto-Tertiary and Madro-Tertiary geofloras, closely resemble plants still living in the nearby area and in adjacent California.

TABLE 4

Distribution of Living Woody Plants Related to Verdi Species

\begin{tabular}{|c|c|c|c|}
\hline \multirow[b]{2}{*}{ Living plants similar to Verdi species } & \multicolumn{3}{|c|}{ Areas of present occurrence } \\
\hline & $\begin{array}{c}\text { Truckee River } \\
\text { valley near } \\
\text { Verdi area }\end{array}$ & $\begin{array}{l}\text { Lower western } \\
\text { slopes, central } \\
\text { Sierra Nevada }\end{array}$ & $\begin{array}{l}\text { Mountains } \\
\text { of southern } \\
\text { California }\end{array}$ \\
\hline Abies concolor . . . . . . . . . . . . . . . & $x$ & $x$ & $x$ \\
\hline Arctostaphylos nevadensis. . . . . . . . . . . & $x$ & $x$ & $x$ \\
\hline 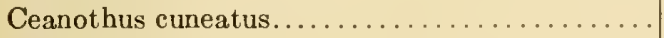 & . & $x$ & $x$ \\
\hline 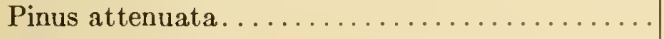 & . & $x$ & $x$ \\
\hline Pinus lambertiana . . . . . . . . . . . . . . & $x$ & $x$ & $x$ \\
\hline 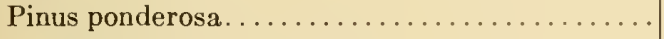 & $x$ & $x$ & X \\
\hline Populus tremula davidiana................. & $\ldots \ldots \ldots(n$ & ortheastern $\mathrm{A}$ & . . \\
\hline Populus tremuloides..................... & $\mathrm{x}$ & $\times$ & $x$ \\
\hline Populus trichocarpa.................... & $x$ & $x$ & $x$ \\
\hline 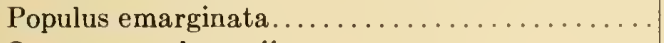 & $x$ & $x$ & $x$ \\
\hline 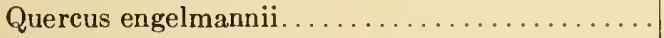 & . & . & $x$ \\
\hline 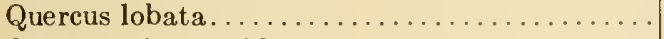 & . & $x$ & $x$ \\
\hline Quercus wislizenoides................ & . & $x$ & $x$ \\
\hline Ribes roezlii.................... & $x$ & $\times$ & $x$ \\
\hline Salix gooddingii................... & . & $x$ & $x$ \\
\hline Salix scouleriana. .................... & $x$ & $x$ & $x$ \\
\hline Number of species. . & 9 & 14 & 15 \\
\hline 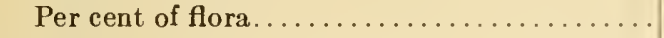 & 56 & 87 & 93 \\
\hline
\end{tabular}

Note: The three aquatics (Potamogeton, Chara, Nymphneites) are excluded from consideration here for they occur in all the areas and have little paleoerologic significance other than indicating standing water-bodies.

\section{PALEOECOLOGY}

By analyzing the ecologic occurrence and distribution of the living species most similar to the Verdi plants it is possible to reconstruct the vegetation and climate of the Verdi basin, and to relate them to the topographic setting which has been suggested by the geologic evidence. Table 4 has been assembled to facilitate this survey of modern vegetation related to the fossil flora. It shows that 9 ( 56 per cent) of the 16 woody plants have close counterparts living within 2 to 3 miles of the fossil locality. Some of them, including Pinus ponderosa, Populus trichocarpa, Prunus emarginata, Ribes roezlii, and Salix scouleriana, occur on the banks of the Truckee River within 200 to 300 yards of the fossil locality. They are regular members of the Sierran forest, which covers the lower mountain slopes directly west and south of the locality, as shown in figure 1, plate 13 . They have descended into the semi- 
arid Truckee River valley, where there is a permanent supply of water through the year, and down which cold air drains at night to moderate the high summer temperature of the valley floor. In the bordering hills south of the locality, these hardier Sierran forest species are associated with Abies concolor, Arctostaphylos nevadensis, Pinus lambertiana, and Populus tremuloides, all of which have close relatives in the Verdi flora.

As shown in table 4, the modern representative species of the Sierra-Cascade Component which live in the Verdi area occur also in the region west of the Sierra Nevada, where they are associated with plants that have fossil relatives in the Verdi flora, but which no longer occur to the east of the range. Clearly, the present environment in the Verdi area differs somewhat from that which prevailed there when the flora was living. Significantly, the dominant species of the flora, Populus alexanderi, has leaves that are much smaller than those produced by its nearest relative ( $P$. trichocarpa) which dominates stream banks in the Verdi area today, as may be seen from a comparison of the figures on plate 19 with those on plate 20 . They also differ from them in shape, being typically oval to suborbicular, rather than ovate-lanceolate. It is only in the warmer, subhumid sections of the south Coast Ranges of California and in southern California that $P$. trichocarpa produces leaves that are closely similar in size and in shape to those of the dominant Verdi cottonwood, as shown on plates 19 and 21. In these warmer areas, the smaller-leafed ecotype ranges from oak woodland and chaparral country of the lowlands up to near the margins of yellow pine forest. Since the small leaves of P. alexanderi dominate the Verdi flora, it is evident that the Sierra Cascade Component was living under conditions more nearly like those now found near the lower margin of yellow pine forest west of the Sierran barrier where black cottonwood produces small, ovate leaves, similar to the fossil $P$. alexanderi.

Five of the six modern equivalent Verdi species that are chiefly members of woodland and chaparral vegetation live on the lower west slopes of the Sierra Nevada together with the Sierran forest species that have close Verdi relatives. These woodland plants include Quercus wislizenii (wislizenoides) ${ }^{2}$ and $Q$. lobata (prelobata), which form a mixed woodland and savanna that interfingers with the lower margins of the Sierran forest; by contrast, on the colder, east flank of the range this ecologic position is occupied by the piñon-juniper woodland. Although Quercus engelmannii (renoana) is not represented in the Sierran foothills, it has an ecologic counterpart there in $Q$. douglasii, which is found commonly with $Q$. wislizenii and $Q$. lobata. These oaks regularly mingle with yellow pine, white fir, sugar pine, willow, and goaseberry, which are similar to fossil species comprising the Sierra-Cascade Component of the Verdi flora. Plate 14 shows two areas near Placerville and Jackson where these oak woodland and forest species live in close proximity. Chaparral is common in the region, and regularly interrupts the continuity of woodland and forest. In these areas Ceanothus cuneatus (precuneatus) is abundant, and black willow, Salix gooddingii (truckeana), is common on stream banks. Pinus attenuata (pretuberculata) is scattered discontinuously in the region, forming relatively pure stands on rocky sites in the forest-woodland ecotone.

\footnotetext{
${ }^{2}$ Species in parentheses are fossil plants similar to the living species.
} 
Populus tremuloides ( $P$. pliotremuloides) is the only Sierran forest species having an equivalent in the Verdi flora that does not range down into oak woodland country today. In recent years, however, it has been found at no great distance from oak woodland. The occurrence of aspen on the north rim of Hetch Hetchy valley where it is within half a mile of digger pine, live oak, toyon, buckbrush, and their regular associates has been noted ( $\Lambda$ xelrod, 1944b, p. 153). More recently, it has been observed in the middle part of the Sierran forest mixed in with black oak, incense cedar, Douglas fir, Pacific dogwood, big-leaf maple, yellow pine, sugar pine, and other common Sierran species. ${ }^{3}$ A mile southward, across a low ridge, live oaks and chaparral occur in abundance. During the Pliocene, aspen has been recorded with redwood forest, oak woodland, chaparral, and desert-border vegetation. On the basis of such present and past occurrences, it has been suggested that $P$. pliotremuloides was represented by one or more extinct ecotypes which extended its range well into mild-winter regions where it lived with communities with which its modern counterpart is no longer found (Axelrod, 1941).

The climatic contrast between the Verdi area today, and that on the west slope of the Sierra Nevada where 14 of the 16 ( 87 per cent) woody Verdi species find their nearest relatives living in close association, is suggested by the data in table 5 . The precipitation figure is somewhat misleading, however, because rainfall at the lower margin of the Sierran forest varies greatly. In areas north of Placerville it exceeds 50 inches in the zone of overlap between forest and woodland. To southward, the ecotone occurs in areas where rainfall is 25 inches, and in favorable topographic situations tongues of forest often extend down the valleys into woodland country where rainfall is only 20 inches. In evaluating modern environments in terms of Verdi precipitation, the small-leafed ecotype of Populus trichocarpa, which is the nearest analogue of the dominant Verdi $P$. alexanderi, probably provides the best indication of rainfall. At one extreme, as in the south Coast Ranges and in southern California, it occurs in mild-winter, lowland areas far removed from forest where rainfall varies from 15 to 18 inches yearly. At the other, it ranges up to near the lower margin of yellow pine forest where precipitation is approximately 25 inches. In areas of higher rainfall, which is correlated with increased altitude and lower temperature, the small-leafed ecotype is replaced by the larger-leafed form of $P$. trichocarpa which is not as closely related to the fossil $P$. alexanderi. It would appear, therefore, that at a maximum, rainfall at the lower edge of forest in the Verdi area probably was not in excess of 25 inches. Since the Verdi forest appears to have lived chiefly in valleys flanking the floodplain where the flora accumulated, it is concluded that precipitation over the Verdi basin averaged 18 to 20 inches. This estimate for the Verdi site of deposition is approximately 5 inches more than that at the Verdi locality today. The decrease can be ascribed chiefly to the rain-shadow cast by the mountainous region to the west which was elevated after the Coal Valley formation was deposited. When the topographic factor is taken into account, there appears to have been no significant difference between total rainfall in the Verdi area and that which might otherwise now be expected in the area. In fact, if the regional topography during Verdi deposition could be restored, it seems probable that precipitation there would now

\footnotetext{
8 These aspen groves are on State Highway 20 just south of Lake Spaulding at an altitude of 5,200 feet.
} 
be several inches more than that under which the Verdi flora lived. Similar climatic relations have previously been reported for several Middle Pliocene floras in the western United States (Axelrod, 1948).

The temperature contrasts between the Verdi area and those which commonly prevail in central California in areas where the flora finds many of its nearest related species are shown in table 5. Summer temperatures are broadly similar, though they are higher on the west front of the range. The major difference is in winter temperature. Both the average January minimum ( $31^{\circ}$ F. vs. $20^{\circ} \mathrm{F}$.) and the average January temperature $\left(42.5^{\circ} \mathrm{F}\right.$. vs. $31^{\circ} \mathrm{F}$.) are from $10^{\circ}$ to $12^{\circ}$ higher

TABLE 5

Comparative Climatic Data for Verdi Area and for Regions Where the Verdi Flora Has Most of Its Modern Relatives

\begin{tabular}{|c|c|c|c|c|c|c|}
\hline & \multicolumn{3}{|c|}{ Central California } & \multicolumn{3}{|c|}{ Southern California } \\
\hline & Verdi & $\begin{array}{l}\text { Grass } \\
\text { Valley }\end{array}$ & Placerville & Mt. Wilson & Idyllwild & Mill Creek \\
\hline Yearly rainfall (inches).......... & 12 & 51 & 35 & 32 & 26 & 23 \\
\hline Average annual temperature $\left({ }^{\circ} \mathrm{F}.\right)$. & 48 & 57 & 55 & 55 & 51 & 62 \\
\hline \multicolumn{7}{|l|}{ Summer temperature $\left({ }^{\circ} \mathrm{F}.\right)$} \\
\hline Average July........... & 70 & 75 & 72 & 73 & 67 & 77 \\
\hline Average July maximum.. & 86 & 89 & 91 & 83 & 86 & 90 \\
\hline Extreme high......... & 102 & 104 & 114 & 101 & 99 & 108 \\
\hline \multicolumn{7}{|l|}{ Winter temperature $\left({ }^{\circ} \mathrm{F}.\right)$} \\
\hline Average January........... & 31 & 43 & 41 & 43 & 40 & 49 \\
\hline Average January minimum. . & 19 & 34 & 31 & 34 & $27^{\circledR}$ & 41 \\
\hline Extreme low............... & -19 & -1 & -9 & 7 & 6 & 16 \\
\hline \multirow{2}{*}{$\begin{array}{l}\text { Growing season (days between } \\
\text { last killing frost in spring and } \\
\text { first in the fall) } \ldots \ldots \ldots \ldots \ldots \ldots\end{array}$} & & & & & & \\
\hline & 145 & 211 & 182 & 176 & $151^{\mathrm{a}}$ & 247 \\
\hline
\end{tabular}

a These low figures are due to the station's site in a valley with cold air drainage.

in areas where the Sierran forest mingles with oak woodland and chaparral. The milder winters on the west slope are reflected in a six-week longer growing season as compared with the Verdi area today.

That winter temperature at Verdi may have been even more mild than that now found on the lower west Sierran slope is suggested by the temperature requirements of the modern ecotype of Populus trichocarpa which most closely resembles the dominant Verdi cottonwood, $P$. alexanderi. The small-leafed ecotype of black cottonwood is found chiefly in areas below the Sierran forest. As judged from field and herbarium studies, it ranges through the south Coast Ranges (lower Carmel River valley; Salinas Valley; Santa Ynez River; Sisquoc River) and into southern California (Santa Clara Valley; Ventura River; lower Sespe Creek; lower Piru Creek; canyons of Santa Monica and Santa Ana mountains; lower canyons of San Gabriel and San Bernardino mountains). In these areas the mean January temperature is from $45^{\circ}$ to $52^{\circ}$, or about $5^{\circ}$ to $10^{\circ}$ higher than on the west Sierran slope in the forest-woodland ecotone. Furthermore, extreme low winter temperatures in its area fall in the range of from $15^{\circ}$ to $30^{\circ}$, and only 
rarely reach $10^{\circ}$, as compared with the Sicrran slope where cxtremes in the ecotone commonly fall below $10^{\circ} \mathrm{F}$. in winter. It is pertinent that black cottonwood is rarely found on the lower Sierran slopes in woodland country, but oceurs usually in the pine-fir forest above woodland, where its leaves are much larger than those of the mild-winter ecotype which so closely resembles the fossil $P$. alexandcri.

It is in the mountains of southern California that this small-leafed ecotype ranges up the canyons to within a few hundred feet (altitudinally) of the lower edge of pine-fir forest. Although the forest generally occurs at levels above 4,500 feet, stringers regularly extend down the deeper canyons to 4,000 feet where they interfinger with woodland and chaparral. Many species that have close equivalents in the Verdi flora occur in such areas, as shown on plates 15 and 16, which are views near the lower margins of forest in the valleys of Mill Creek and the Santa Ana River in the San Bernardino Mountains east of Redlands. Here the forest dominants are Abies concolor (A. concoloroides), Pinus pondcrosa ( $P$. florissanti), and $P$. lambertiana ( $P$. prelambertiana), associated with Prunus emar. ginata ( $P$. moragensis), Ribes roezlii (P. galeana), and Salix scouleriana ( $S$. boisiensis), all of which also live in the Verdi area. Arctostaphylos ncvadcnsis (A. verdiana) and Populus tremuloides (P. pliotremuloides) are in the nearby area at higher levels. Populus trichocarpa ( $P$. alexanderi) occurs on the stream margin in the forest zone, but there its leaves are larger than those of the dominant Verdi species, and are more lanceolate. It is only at lower levels in the oak woodland and chaparral country that black cottonwood produces leaves closely similar to the Verdi dominant. Quercus wislizenii (Q. wislizenoides) is abundant in this region, and extends upward to mingle with forest spceies on exposed, southfacing slopes. Salix gooddingii ( $S$. truckeana) is also more common at lower levels, but is found locally near the pine-fir forest. Three other plants having close relatives in the Verdi flora are in the nearby region. A large stand of Pinus attenuata ( $P$. pretuberculata) is a few miles west of Mill Creek on the City Creek road in the transition from chaparral to yellow pine forest, as illustrated in figure 1, plate 16 . Quercus engelmannii ( $Q$. renoana) is in the foothills of the eastern San Gabriel Mountains near Claremont, 25 miles from the Mill Creek area; in the central part of its range, as on the slopes of Mount Palomar, it extends up to 4,000 feet, where it is at no great distance from yellow pine forest. Quercus lobata (Q. prelobata) has its southern outpost 50 miles northward in the foothills of the San Gabriel Mountains where most of the plants mentioned above also occur.

Present climatic conditions near the lower margin of the yellow pine forest in southern California are suggested by the meteorological data for Mount Wilson and Idyllwild, as listed in table 5. It is apparent that winter temperatures are generally higher than those in the central Sierran area at the lower margins of yellow pine forest. If we recall that forest was confined chiefly to hills surrounding the Verdi basin, and that woodland was in the lowlands on the Verdi floodplain, then temperature at the Verdi site of deposition must have been more mild than that at Mount Wilson and Idyllwild for they are well up in the lower part of the forest zone. Furthermore, at these levels Populus trichocarpa produces larger leaves than the fossil $P$. alexanderi; the small-leafed ecotype of $P$. trichocarpa which most

\footnotetext{
"Species in parentheses are fossil species most nearly related to the living plants.
} 
nearly resembles the fossil occurs generally at altitudes fully 500 to 1,000 feet lower, where winters are more mild. And it is only at these lower levels that oaks and other mild-winter types which have equivalents in the flora are to be found. Although climatic data for intermediate elevations are not available for southern California, they can be estimated in a general way by comparing the data for Mill Creek (table 5) with those at Mount Wilson and Idyllwild. The Mill Creek station is at an elevation of approximately 3,000 feet in the San Bernardino Mountains. The area is dominated by chaparral and sage, with woodland in the region, and with the lower margin of yellow pine forest 3 miles distant and 1,000 feet higher (pl. 16, fig. 2). $\Lambda$ s compared with Mount Wilson and Idyllwild, intermediate temperatures may be inferred for these slopes where tongues of forest are in close proximity to the small-leafed ecotype of $P$. trichocarpa.

On the basis of the preceding discussion, the following temperatures are inferred for the Verdi locality at the time of plant deposition:

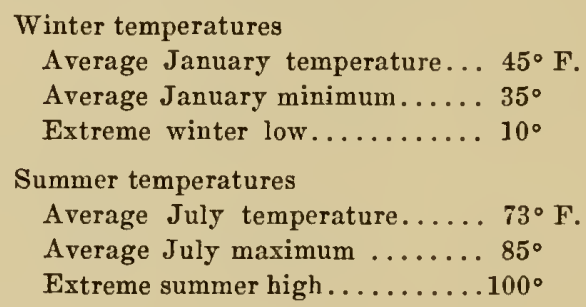

Slightly lower temperatures prevailed in the bordering hills where the SierraCascade Component lived. In the basin proper the growing season probably was not less than 200, and may have been as much as 230 days, as compared with 145 today.

Populus subwashoensis is the only Verdi species that does not have a close relative living in California. It most nearly resembles the smaller leaves produced by $P$. tremula davidiana of northeastern Asia. The Verdi poplar appears to be a small-leafed derivative of the Miocene $P$. washoensis Brown, which has leaves that are similar to those of $P$. tremula and $P$. grandidentata of the eastern United States. Similar relationships between Middle and Late Teritary species have already been reported for such plants as Populus voyana-P. pliotremuloides and $P$. eotremuloides-P. alexanderi, as well as for species of Acer, Amelanchier, Rosa. and other angiosperms. The smaller-leafed Late Tertiary species appear to represent plants that were adapted to the drier, sunnier climate of post-Miocene time (Chaney, 1938a, pp. 212-213; 1944, pp. 16-17; Axelrod, 1941; 1944d).

The climatic significance of $P$. subwashoensis lies in the fact that its nearest modern relative survives in a region of summer rain. Many fossil plants whose descendants are restricted now to temperate regions with ample summer rain, such as beech, chestnut, elm, hickory, hornbeam, tupelo, and swamp cypress, were common as far south as central Nevada in the Miocene. They gradually disappeared from the far West as summer showers were reduced in amount and in frequence during the Pliocene. The presence of only one species at Verdi whose nearest relative is found in a summer-wet area indicates that precipitation was greatly reduced in the warm season as compared with earlier in the epoch. 
With respect to altitude, we have seen that the Verdi flora finds many of its closest relatives living at elevations near 2,000 feet in woodland areas just below forest on the lower west slope of the Sierra Nevada. But this figure does not give us a valid estimate of the altitude of the Verdi basin for the flora lived during the Middle Pliocene, the driest part of the Tertiary (Axelrod, 1948, p. 132). At that time woodland and forest zones were all displaced up the slopes as compared with their present altitudinal relations. Comparisons of Middle Pliocene floras with present vegetation near the fossil localities have indicated that rainfall was approximately 5 to 8 inches lower than at present. This suggests that the forest zone would have occupied a position at least 500 feet above its present level. Applying this correction factor, it would appear that the Verdi basin had an altitude near 2,500 feet.

\section{SUMMARY}

Paleoecologic relations in the Verdi area, as inferred from geologic evidence, the relative abundance of the fossil species, and the ecologic occurrence of living plants similar to the fossils, may be summarized as follows:

Geologic setting.-The Coal Valley sediments in the Verdi area were deposited in a basin situated between the Carson Range and Peavine Mountain, both of which appear to have been relatively low areas during deposition. Clastics from the Carson block were derived chiefly from Kate Peak andesite, and those from the Peavine block largely from Alta andesite. Marginal conglomerates graded into tuffaceous sandstones, shales, and diatomite in the central floodplain area, where small ponds, lakes, and swamps were common at the site of deposition, which had an altitude near 2,500 feet.

Vegetation.-A dense riparian woodland of cottonwood (Populus alexanderi) occupied the stream margins in the Verdi lowlands, together with willow (Salix truckeana). The ponds, lakes, and swamps supported colonies of water lily (Nymphaeites), pondweed ( Potamogeton), and stonewort (Chara).

A forest dominated by fir (Abies concoloroides) and pine (Pinus florissanti, $P$. prelambertiana), with associates of poplar (Populus subwashoensis), aspen ( $P$. pliotremuloides), and willow (Salix boisiensis) on the stream-borders, and with manzanita (Arctostaphylos verdiana), bitter cherry (Prunus moragensis), and gooseberry (Ribes galeana) on the forest floor, was confined chiefly to moister valleys and slopes bordering the basin; they appear to have been transported into the lowlands largely at times of flood. Aspen and poplar, however, extended into the lowlands on stream banks in moderate numbers.

Valley oak (Quercus prelobata) and live oaks (Q. renoana, Q. wislizenoides) formed a mixed woodland and savanna on well-drained, drier slopes and flats, and the more abundant riparian species also ranged into this area. Buckbrush (Ceanothus precuneatus) was scattered in the woodland, and may have contributed to a chaparral together with other shrubs that are still unrecorded in this flora. Closed-cone pine (Pinus pretuberculata) probably occupied rocky, exposed slopes in the woodland-forest ecotone.

Climate.-Rainfall is estimated to have averaged 18 to 20 inches over the lower part of the basin, increasing to 25 inches at the edge of forest in the bordering 
hills. Precipitation was distributed chiefly in winter, though summer showers were present in minor amount. Summers were warm to hot, with the average July maximum approximately $85^{\circ} \mathrm{F}$. The average January temperature was approximately $45^{\circ} \mathrm{F}$., which is about $15^{\circ} \mathrm{F}$. higher than that now in the area. Extreme winter temperatures apparently did not fall much below $10^{\circ} \mathrm{F}$., as compared with $-19^{\circ} \mathrm{F}$. today. The growing season probably was not less than 200 to 230 days, whereas it is now 145 days.

\section{AGE}

\section{Stratigraphic Evidence}

The sediments in the Verdi area were originally considered to be of Miocene age. This assignment was based on the age implication of a fragmentary rhinoceros tooth and a small fresh-water molluscan fauna recovered from the basal-type Truckee formation at Fossil Hill in the northeastern Hot Springs (Kawsoh) Mountains 60 miles northeast of Verdi (King, 1878, vol. 1, pp. 423-424). Since the sediments in the Verdi area were tilted to about the same degree as the Truckee, it was concluded that they were of approximately the same age (King, 1878, vol. 2, p. 849). Although the Verdi sediments appear on the Atlas of the Fortieth Parallel Survey as Truckee, King (1878, vol. 2 , p. 849) clearly realized that the Verdi section differed lithologically from the type Truckee.

Mammalian faunas having greater age value than the rhinoceros tooth have been discovered more recently at two localities in the lower part of the Truckee formation. The small Hazen fauna appears to be Late Clarendonian to Early Hemphillian (Stirton, 1939, p. 635). The larger Nightingale Road fauna contains a number of types distinctive of the Late Clarendonian (MacDonald, 1950; 1956). A recent revision of the molluscan fauna, as based on new collections from the original locality in the basal type Truckee section, indicates that it is Pliocene (Yen, 1950). Since the Verdi flora occurs in the Coal Valley formation, which is now known to interfinger with the Truckee in the Carson Sink area (Axelrod, 1956, p. 141), it must also be Pliocene. This age assignment for the Verdi flora, as based on its stratigraphic relations, is supported fully by the paleontological evidence now available in the Verdi basin.

\section{Paleontologic Evidence}

PLANTS

The first fossil plants from the Verdi basin to be evaluated in terms of age were those represented in the small collection that was secured by Anderson. J. P. Smith (in Anderson, 1909, p. 483) identified species of pine, birch, willow, serviceberry, and manzanita in the collection and suggested that it was Miocene; it is worth noting here that Smith's identifications appear to have been far more realistic than those made by Knowlton (see below). Unfortunately, the fossils were neither figured nor referred to fossil species, and although Anderson states that the collection was deposited at Stanford University, it could not be located there. It is to be hoped that this collection can be found, for if birch and serviceberry are represented in it, they will add materially to this small flora. 
Merriam (1916, pp. 166-168), in his paper on the Cedar Mountain mammalian fauna of south-central Nevada, reviewed the age relations of the Truckee and Esmeralda formations from the fossil evidence then in hand. As a basis for this discussion, Merriam turned over to Knowlton his small Verdi collection for study. Knowlton (in Merriam, 1916) identified twelve species, of which six were considered to be present in the Esmeralda flora 130 miles southeast. From this presumed relationship with the Esmeralda, which was then regarded as Miocene, Knowlton concluded the Verdi also was Miocene. The original list of twelve species was not published by Merriam, and the fossils identified by Knowlton were not labeled permanently, so it is not possible to evaluate his identifications with certainty. Nonetheless, a comparison of the six Esmeralda species with the Verdi plants that Knowlton thought were similar, suggests that the following identifications may be inore nearly correct:

Knowlton's identifications of $\nabla$ erdi species

Cercis nevadensis? Knowlton Chrysobalanus pollardiana Knowlton Ficus? lacustris Knowlton Rhus? nevadensis Knowlton Salix angusta A. Braun Salix sp. Knowlton

\section{Present interpretation}

Populus pliotremuloides Axelrod

Populus alexanderi Dorf

Populus alexanderi Dorf

Arctostaphylos verdiana Axelrod

Salix truckeana Chaney

Salix truckeana Chaney

In any event, on the basis of my studies of both floras it is certain that not more than one species (Populus pliotremuloides) was common to the collections examined by Knowlton. This is not surprising, for the Early Pliocene Esmeralda is dominated by live oak woodland, chaparral, and desert-border vegetation ( $A$ xelrod, 1940), and would thus be expected to have but little in common with the Verdi.

It was Chaney (1938b, p. 388) who was the first to express the opinion that the Verdi flora was Pliocene. He noted that the rarity of forest species in the flora, and the dominance of stream-border types in it, were consistent with a Pliocene age assignment.

The fossil plants comprising the Verdi flora not only demonstrate its Pliocene age, but also afford critical evidence with respect to its position within the epoch. The distribution of its woody plants in other floras in the far West is shown in table $6 .{ }^{5}$ Five identical and 5 related species are known from Miocene floras; 13 identical and 2 similar species have been recorded in transitional Mio-Pliocene floras; 5 identical and 4 related species are reported in the late Early Pliocene; 8 identical and 2 related species are known in the Middle Pliocene; and 7 identical and 2 similar species have been recognized in Late Pliocene floras. Among the MioPliocene floras, closest relationship is apparent with the Chloropagus, Middlegate, and Aldrich Station floras of western Nevada (Axelrod, 1956), each of which has from 5 to 7 species in common with the Verdi. Pertinently, the Late Pliocene Napa flora of California (Axelrod, 1950a) has as many species in common with the Verdi as do these nearby Mio-Pliocene floras.

\footnotetext{
${ }^{5}$ Excluded from consideration are three aquaties (Chara, Nymphaeites, and Potamogeton), which have little age significance, and two of the new woody plants (Arctostaphylos verdiana and Ribes galeana), which are now known only from the Verdi flora and do not have close relatives in other floras.
} 


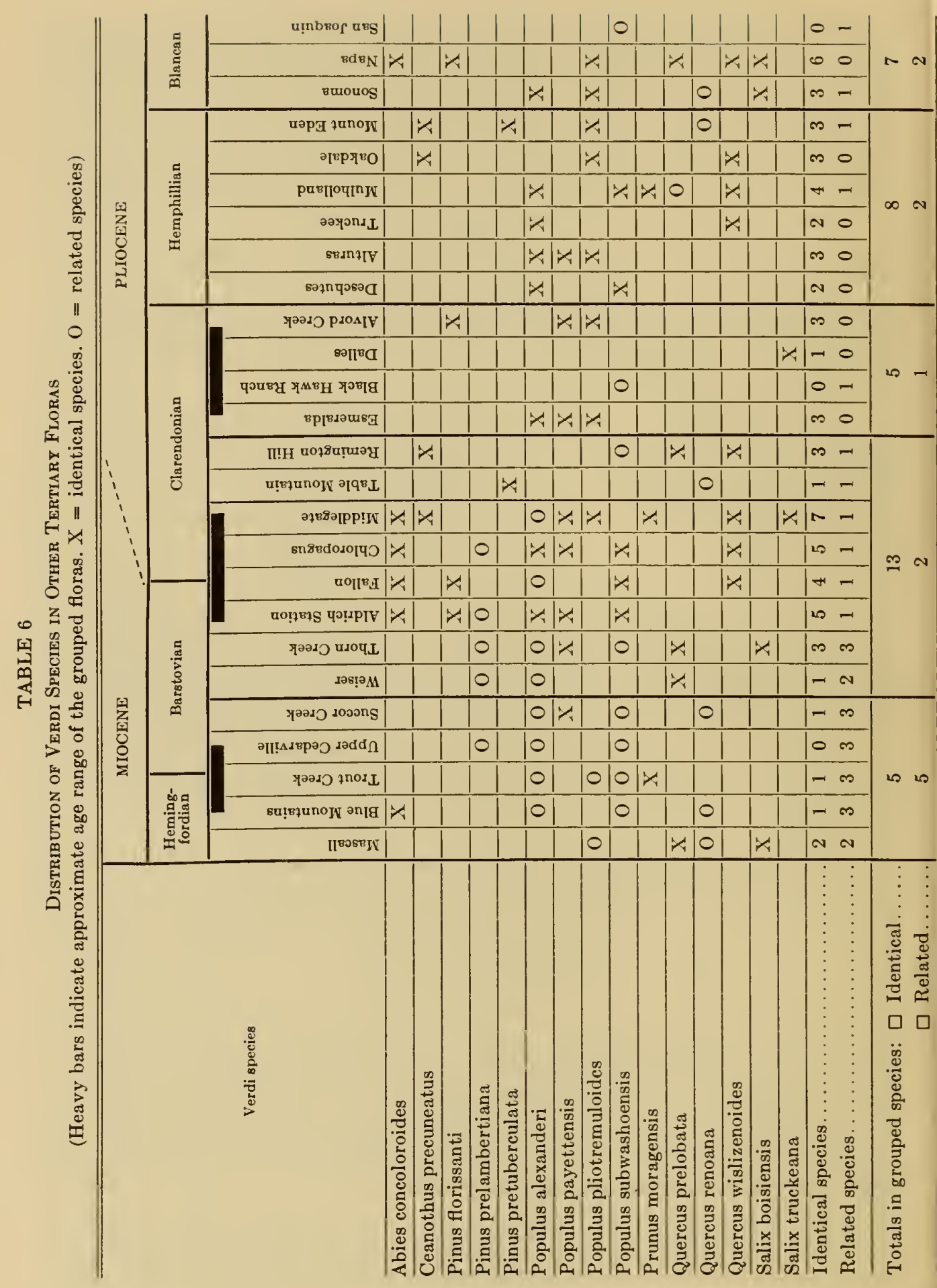


The floras having the largest numbers of species in common with the Verdi are all characterized by a prominent Sierra-Cascade Component. Floras with few or no species representing this group, which forms all important part of the Verdi flora, even though of the same age, obviously could not be expected to have many species in common with it. This explains why the Mio-Pliocene Remington Hill (Condit, 1944a) and Table Mountain (Condit, 1944b) floras of the west Sierran slope, though situated at no greater distance from Verdi than the Mio-Pliocene floras of west-central Nevada, have so little in common with the Verdi: they represent different forests. Thus, as we shall see below, even though the Middle Pliocene Deschutes, Alturas, Truckee, Mulholland, Mount Eden, and Oakdale floras each have only 2 to 3 species in common with the Verdi, all of them are of the same age; there are few species common to these floras simply because they represent different types of vegetation. It is apparent that comparisons on a strictly numerical basis may be quite misleading in terms of age assignment, particularly in Late Tertiary time when localized climates had a profound effect on the distribution and composition of vegetation.

As discussed in detail elsewhere (Axelrod, 1938, 1944c; 1948; 1949b; 1956), age determination of Late Tertiary floras must be based on lines of evidence other than the strictly stratigraphic ranges of individual species. By contrast, we must be collcerned with the evolution of floras in time and space. In the case of the Verdi flora, data for age evaluation are provided by an analysis of (1) its geographic relations, (2) its climatic implications, and (3) its cliseral aspects, all in terms of the temporal succession of vegetation in this region. Similar floras in other areas are homotaxial, not synchronous.

Geographic occurrence.-A close relation exists between the age of a Tertiary flora, the type of vegetation it represents, and the proximity of regions in which living species similar to the fossil are found. These relations for western Nevada, as outlined in table 7, show that the flora is not Early Tertiary, for there are no plants in it that have relatives in tropical or subtropical regions. Nor can it be Middle Tertiary, for floras of that age in this region are dominated by deciduous hardwoods that are represented by close counterparts in eastern North America and eastern Asia. The flora must also be younger than the Mio-Pliocene transition. The Mio-Pliocene floras of the Carson Sink area 50 miles east have a prominent forest group that has persisted in the Sierra Nevada, as well as species related to those in the temperate parts of eastern North America and eastern Asia (Axelrod, 1956). A flora of similar age in the Verdi area should, on the basis of its geographic position, be more humid than the Carson Sink floras, and hence contain a larger number of species allied to those now in the Sierra Nevada and in the eastern parts of the northern continents. It is apparent that the Verdi must be post-Mio-Pliocene (Early Clarendonian).

Relatively little is known of the younger floras of this region. The Late Clarendonian Esmeralda flora has a few species with modern relatives in more remote areas, as in the southwestern United States, but most occur on the lower slopes of the southern Sierra Nevada and in southern California. Many of the species in the small Middle Pliocene (Hemphillian) Truckee floras also have their closest relatives in southern California and at low elevations on the west Sierran slope. These 
are areas where the Verdi shows relationship to modern vegetation. The available data, although incomplete, suggest that on the basis of its geographic relations to modern vegetation the Verdi flora is not older than Late Clarendonian, and is more probably of Hemphillian age.

Climatic implications.-Late Tertiary plants are scarcely distinguishable from living species, and most of them formed communities that closely resemble modern associations. The physical conditions under which these related communities now

TABLE 7

Cliseral, Geographic, and Climatic Relations of Tertiary Vegetation in Western NeVAda

\begin{tabular}{|c|c|c|c|}
\hline Age & $\begin{array}{l}\text { Kinds of vegetation at } \\
\text { site of deposition }\end{array}$ & $\begin{array}{l}\text { Regions with related } \\
\text { modern vegetation" }\end{array}$ & Climate \\
\hline Pliocene & $\begin{array}{l}\text { Riparian woodland } \\
\text { Oak woodland and savanna; } \\
\text { Chaparral }\end{array}$ & $\begin{array}{l}\text { Nearby region; southern } \\
\text { California } \\
\text { Central-southern California; } \\
\text { southwestern United States }\end{array}$ & Semiarid \\
\hline Mio-Pliocene & $\begin{array}{l}\text { Oak woodland, chaparral } \\
\text { Montane forest } \\
\text { Deciduous hardwood forest }\end{array}$ & $\begin{array}{l}\text { South-central California; } \\
\text { southwestern United States } \\
\text { Sierra Nevada to Rocky Mts. } \\
\text { Eastern America, Eastern } \\
\text { Asia }\end{array}$ & Subhumid \\
\hline Miocene & $\begin{array}{l}\text { Deciduous hardwood forest } \\
\text { Montane forest } \\
\text { Oak woodland }\end{array}$ & $\begin{array}{l}\text { Eastern America, Eastern } \\
\text { Asia } \\
\text { Western North America } \\
\text { Southwestern North America }\end{array}$ & Temperate \\
\hline Oligocene & $\begin{array}{l}\text { Warm temperate forest } \\
\text { Deciduous hardwood forest }\end{array}$ & $\begin{array}{l}\text { Southeast China; Gulf States } \\
\text { Eastern Asia, Eastern } \\
\text { America }\end{array}$ & $\begin{array}{l}\text { Warm } \\
\text { temperate }\end{array}$ \\
\hline Eocene & Tropical to subtropical forest & Tropical America and Asia & Tropical \\
\hline
\end{tabular}

- Vegetation types and areas of modern occurrence are listed in order of relative importance for each epoch.

live not only provide an index to past climate, but also to age. Comparisons of numerous Tertiary floras in the western United States have shown that there was a gradual shift from warm, moist tropical climate carly in the Tertiary, to cool, semiarid climate near the close of the period (Chaney, 1938b; 1948).

Table 7 shows that with respect to climate in western Nevada, Early Tertiary floras were tropical to subtropical, Middle Tertiary floras were humid temperate, and Late Tertiary floras range from subhumid to semiarid. The semiarid aspect of the Verdi flora, as discussed in the preceding chapter, thus demonstrates its Late Tertiary age. A sufficient number of Late Tertiary floras is now known to give us some insight into the details of climate in the far West at that time. In this region there appears to be good evidence for asserting that Early Pliocene climate was considerably moister and warmer than present-day conditions at a given fossil 
locality over lowland regions. Middle Piocene floras suggest a mild, semiarid climate, often one that was warmer and drier than exists at fossil localitics today in areas outside of the present desert region; in the present desert areas these floras indicate mild, semiarid climate (Axelrod, 1948; 1950d). Although only a few Late Pliocene floras are now known in the far West, they suggest a climate more moist than that which prevailed in the Middle Pliocene. Thus the Middle Pliocene appears to represent the driest part of the Tertiary (Axelrod, 1948). The relatively warm, semiarid to subhumid climate of the Verdi area, and the general correspondence of its rainfall to that which might be expected there today after the topographic factor has been taken into account, have been noted above. Furthermore, there are indications that the climate was actually drier than that which might prevail there today if Pliocene paleogeography could be restored. Thus in its general climatic implications the flora appears to be Middle Pliocene (Hemphillian).

Cliseral relations.-A clisere represents a series of plant formations (or climaxes) that succeed one another in a region in response to secular climatic change. As outlined in table 7, the cliseral relations of Tertiary floras in this region show a shift from tropical forests in the Early Tertiary, to temperate deciduous hardwood forests in the Middle Tertiary, to subhumid and semiarid open forest. woodland, and shrub communities in the Late Tertiary. The following brief statements, which summarize some of the details of the cliseral relations of the $(a)$ Arcto-Tertiary and (b) Madro-Tertiary Geofloras in western Nevada during Miocene and Pliocene times, provide additional evidence as to the age of the Verdi flora.

(1) During the Miocene, the Arcto-Tertiary Geoflora was characterized by members of the East American and East Asian Elements, groups of fossil plants which resemble deciduous hardwoods and conifers now in the temperate forests of eastern Asia and eastern North America. Species of these elements dominate the Middle Miocene Pyramid flora 35 miles northeast of Verdi; they are present in moderate numbers in the Late Miocene Buffalo Canyon flora 120 miles southeast; they are uncommon in the transitional Mio-Pliocene Fallon, Chloropagus, Middlegate, and Aldrich station floras of west-central Nevada; and they are rare in the Early Pliocene Chalk Hills and Lewis Coal Mine floras, both of which occur at low stratigraphic levels in the Coal Valley formation to the southeast. The only Verdi species that can be referred to these eastern elements is Populus subwashoensis, the small-leafed derivative of $P$. washoensis Brown which was in this region in the Miocene and Early Pliocene (Chalk Hills flora). These relationships indicate the post-Early Pliocene age of the Verdi flora, and suggest it is Middle (Hemphillian) rather than late Early Pliocene (Late Clarendonian).

As deciduous hardwoods of the eastern elements gradually were reduced in numbers, their place was taken chiefly by members of the West American Element, which show relationship to plants now forming the western conifer forests. Members of this element are rare in the Middle Miocene Pyramid flora; present in small numbers in the Upper Miocene Buffalo Canyon flora; common in the Mio-Pliocene Fallon, Chloropagus, Aldrich Station, and Middlegate floras; and they dominate the Early Pliocene Chalk Hills flora. During the Verdi stage, however, the forest 
dominants were restricted chiefly to moister bordering slopes and canyons, and only the hardier stream-border types of the West American Element were common in the lowlands. The wide restriction of forest over lowlands of the Verdi area not only demonstrates its Pliocene age, as Chaney has earlier noted (1938b, p. 388), but also suggests the flora is Middle Pliocene (Axelrod, 1948, p. 131). In this connection, it is pertinent that whereas the large-leafed Populus eotremuloides Knowlton is dominant in the nearby Chalk Hills flora, at Verdi it is represented by the derivative, smaller-leafed $P$. alexanderi. This relation is also consistent with a Middle Pliocene (Hemphillian) age.

(2) In western Nevada, the Madro-Tertiary Geoflora was characterized by woodland and chaparral, arid subtropical scrub being confined to warmer regions at lower latitudes (Axelrod, 1950b). There are no known records of this geoflora in the nearby Middle Miocene Pyramid flora; it occurs in moderate numbers in the Late Miocene Buffalo Canyon flora ; it is abundant in the Mio-Pliocene Chloropagus, Fallon, Aldrich Station, and Middlegate floras of west-central Nevada, and dominates the Early Pliocene Esmeralda flora of south-central Nevada. To judge from the small Truckee floras, it was represented chiefly by hardier stream-border types and seattered oak savanna during the Middle Pliocene (Hemphillian), when grasslands are inferred to have become more prominent at the expense of woodland. The California Woodland and Chaparral Elements are no longer represented by equivalent species in the region, though the Conifer-Woodland Element has persisted down to the present day on slopes above the desert as piñon-juniper woodland. To judge from the nearby Chalk Hills flora, which is dominated by species of the Arcto-Tertiary Geoflora, and in which Madro-Tertiary species are rare, Madro-Tertiary species did not invade the east margin of the Sierran slope until later in the Pliocene when the climate was drier. These relationships are fully consistent with a Middle Pliocene age for the Verdi flora. A Late Pliocene (Blancan) age seems unlikely for the climate was then cooler and moister, and the MadroTertiary plants that now survive in milder regions probably would not have persisted in the area to such a late date.

One further point must be made with respect to plant evidence regarding the age of the flora. It has been suggested that the percentage of genera in a fossil flora that still live in the region of the fossil locality provides a measure of age because, in general, the percentage decreases from 100 in Recent floras to a very low figure for those of Early Tertiary age (Barghoorn, 1951). All of the Verdi genera still live near the locality. Chara, Potamogeton, and Nymphaea are common in nearby ponds and backswamps on the Truckee River floodplain, Ceanothus, Pinus, Populus, Prunus, Ribes, and Salix occur within 200 yards of the fossil locality, and Abies, Arctostaphylos, and Quercus are in canyons on the north front of the Carson Range 2 miles distant. Since all of the genera (100 per cent) are in the immediate area, the Verdi would be of Recent age according to the method of age analysis proposed by Barghoorn. The inherent weaknesses of the method as applied to age analysis of Tertiary floras have been outlined elsewhere (Axelrod, 1957b) and need not be reviewed here. 


\section{MAMMALS}

Although fragmentary remains of mammalian fossils (chiefly broken limb bones) have been found at several sites in the Coal Valley formation in the Verdi region, at the present time only three spccimens are known which provide evidence of age. The mastodont tooth described by Buwalda (1914) comes from a locality approximately 1 mile southwest of the Verdi flora, and about 500 feet above it stratigraphically. In view of the fragmentary nature of this fossil, which Buwalda identified as Tetrabelodon (?), his discussion of its age significance was necessarily indefinite though he seemed to consider it Late Miocenc. Stirton (1939, p. 635) has pointed out that it does not differ appreciably from certain Lower Pliocene specimens in the San Francisco Bay region which have been referred to ?Trilophodon simpsoni. However, he stressed the fact that the tooth is not diagnostic in terms of close age assignment. In a recent discussion (Sept., 1956) he has indicated that it could well be Middle Piocene (Hemphillian).

Another mastodont tooth, now in the museum of the Mackay School of Mines at the University of Nevada, comes from Mogul east of the flora, and approximately 600 feet lower in the section. According to Donald E. Savage (written communication, Jan. 17, 1956) : “. . It is a left $\mathrm{M}^{2}$ of a mammutid (true) mastodon. It can be called Miomastodon? or Pliomastodon?; both are rather intangible subgenera of Mammut. Age. Barstovian to Hemphillian, possibly Clarendonian from meagre evidence. The tooth shows some differences from the Pliomastodon? of the Smith's Valley fauna but could be the same." The Smith's Valley fauna is considered Middle Pliocene (mid-Hemphillian) by vertebrate paleontologists.

A fragmentary lower premolar of a Hipparion or a Neohipparion was collected in the spring of 1951 by Ira LaRivers, of the University of Nevada, at a locality 1 mile north of Mogul, where it occurs in the upper member, about 400 feet below the flora. R. A. Stirton examined the specimen and has reported (written communication, May 1951) that it is evidently of Pliocene age.

It is apparent that the Middle Pliocene (Hemphillian) age of the Verdi flora, as deduced from paleobotanical evidence, is supported by the age implications of the fragmentary mammalian fossils that are now known in the Verdi basin. Since the highest part of the Coal Valley section, which is exposed along the highway at the west edge of Reno, is stratigraphically not less than 1,500 feet above the Verdi flora, those rocks may well range into the Upper Pliocene (Blancan).

\section{SYSTEMATIC DESCRIPTIONS}

\section{Family CHARACEAE}

\section{Chara verdiana $\mathrm{n} . \mathrm{sp}$.}

(Pl. 18, fig. 2)

Description.-Terminal branch $7.5 \mathrm{~cm}$. long, stem $1.0 \mathrm{~mm}$. wide, divided into nodes and long internodes spaced from 7 to $8 \mathrm{~mm}$. apart in the middle and lower parts of the axis, somewhat shorter above; lateral branches whorled, rather numerous at the nodes, $5 \mathrm{~mm}$. wide or less, and up to $1.7 \mathrm{~cm}$. long; tips narrowly acuminate. 
Discussion.-There are well over 150 records of Chara in Europe, ranging from the Devonian to the Pleistocene, but less than a dozen have been recorded from North America. These range from the Late Mesozoic into the Pleistocene, and are represented by fruiting bodies. The nearest fossil occurrences to western Nevada are those reported from Florissant (Oligocene), New Mexico (Pleistocene), and Utah (Eocene); for references to these and other records, see LaMotte, 1952, p. 123.

Chara is found commonly in fresh to brackish water, where it grows attached to the bottom and often forms large colonies covering considerable areas. Sometimes the branches become incrusted with lime (hence the name stonewort), which would generally tend to make their preservation more likely. The regular occurrence of Chara in small ponded water-bodies suggests the probable nature of its distribution on the Verdi floodplain.

Occurrence.-Verdi, Nev.: U.C. Mus. Pal. (loc. P102), holotype no. 1961.

\section{FAMILY PINACEAE}

\section{Abies concoloroides Brown}

(Pl. 19, figs. 1-2, 5-6)

Abies concoloroides Brown, Jour. Wash. Acad. Sci., vol. 20, p. 347, 1940 (see synonymy \& diseussion) ; Axelrod, Univ. Calif. Publ. Geol. Sci., vol. 33, p. 275, pl. 4, figs. 2-6 ; pl. 12, figs. 6-8 ; pl. 17, figs. 5, 6; pl. 25, fig. 5, 1956.

The Verdi fossils, as represented by numerous needles and a few cone-scales, are similar to those produced by the living white fir, Abies concolor Lindley \& Gordon, a widely distributed forest tree in the western United States.

Occurrence.-Verdi, Nev.: U.C. Mus. Pal. (loc. P102), hypotypes nos. 19621963, 1965; homeotypes nos. 1966, 1967, 1964.

\section{Pinus florissanti Lesquereux}

(Pl. 17, fig. 3)

Pinus florissanti Lesquereux, Rept. U.S. Geol. Surv. Terr., vol. 8, p. 138, pl. 21, fig. 13, 1883; MacGinitie, Carnegie Inst. Wash. Pub. 599, p. 84, pl. 18, fig. 12 ; pl. 19, fig. 2 ; pl. 20, figs. 1-3, 1953 ; Axelrod, Univ. Calif. Publ. Geol. Sci., vol. 33, p. 276, pl. 4, figs. 19-20; pl. 17, figs. $10-11,1956$.

The record of yellow pine at Verdi is based on pine cones and cone-scales. The cones can not be recovered readily from the coarse, thick sandstones because they are carbonized and fall to pieces as soon as the rock is disturbed. The material shows close relationship to the modern Pinus ponderosa Douglas on the basis of size, shape, and scale characters. At the present time yellow pine has only a limited occurrence in western Nevada. It is found commonly in deep, protected canyons with conifers that are regularly associated with it on the western slopes of the Sierra Nevada, such as Abies concolor, Libocedrus decurrens, and Pinus lambcrtiana, and which also have a restricted distribution in western Nevada today.

Occurrence.-Verdi, Nev.: U.C. Mus. Pal. (loc. P102), hypotype no. 1968; homeotypes nos. 1969, 1970. 


\section{Pinus prelambertiana n. sp.}

(Pl. 18, figs. 9-12)

Pinus sp. Dorf, Carnegie Inst. Wash. Pub. 412, p. 71, pl. 9, fig. 1, 1930.

The specimen figured by Dorf (1930) from the Santa Clara flora, together with supplementary material from the Verdi flora, provides the basis for the following description:

Description.-Cones up to $21 \mathrm{~cm}$. long, and from 3.5 to $4.0 \mathrm{~cm}$. wide; scales numerous, spirally arranged, the umbos not thickened, distal part of scale broadly tapering, with a subtruncate tip. Needles typieally thin, preserved in 3's and 4's but were originally in 5's, up to $5.0 \mathrm{~cm}$. of length preserved; sheath deciduous.

Discussion.-As the name indicates, this pine is considered to represent a close forerunner of the modern sugar pine, Pinus lambertiana Douglas, a forest giant that ranges from southern Oregon into southern California, and forms an integral part of the yellow pine-white fir forest.

A related species in other floras in the nearby region is $P$. wheeleri Cockerell (Axelrod, 1956), which is represented chiefly by relatively short, slender, 5-needled fascicles. The occasional occurrence of seeds in association with needles of $P$. wheeleri which are smaller than those produced by the living $P$. lambertiana, but of the size of those formed by $P$. monticola Douglas, suggests $P$. whecleri Cockcrell is more nearly related to the latter.

Occurrence.-Santa Clara, Calif.: U.C. Mus. Pal. (loc. P160), holotype no. 309; Verdi, Nev.: U.C. Mus. Pal. (loc. P102), hypotypes nos. 1976-1978.

\section{Pinus pretuberculata Axelrod}

(Pl. 18, figs. 3-4, 11-13)

Pinus pretuberculata Axelrod, Carnegie Inst. Wash. Pub. 476, p. 166, pl. 3, figs. 3, 4, 1937; Condit, Carnegie Inst. Wash. Pub. 553, p. 74, pl. 14, fig. 1, 1944.

Three impressions of cones representing the closed-cone pine group are in the Verdi collections. Their close relationship to cones of the living $P$. tuberculata Gordon ( $=P$. attenuata Lemmon) was revealed by making casts of the molds. As illustrated on plate 18 , they show the typical tuberculate umbos that are so characteristic of the living species. Fascicles of a 3-needled pine are also relatively cominon in the flora. They are assigned to $P$. pretuberculata rather than to $P$. florissanti Lesquereux because the needles are generally shorter and inore slender than those produced by yellow pine, and the sheath is deciduous rather than persistent.

Ranging from southern Oregon southward through California in the Coast Ranges and on the western slope of the Sierra Nevada into southern California, the living $P$. tuberculata is commonly found on rocky sites near the lower margins of forest adjacent to woodland and chaparral vegetation. Many of its associates in the southern parts of its area have close representatives in the Verdi flora.

Occurrence.-Verdi, Nev.: U.S. Nat. Museum; U.C. Mus. Pal. (loc. P102), hypotypes nos. 1972-1975; homeotype no. 1971. 


\section{FAMILY SALICACEAE \\ Populus alexanderi Dorf}

(Pl. 19, figs. 1-11)

Populus alexanderi Dorf, Carnegie Inst. Wash. Pub. 412, p. 75, pl. 6, figs. 10-11 only; pl. 7, figs. 2, 3 only, 1930; Chaney, Carnegie Inst. Wash. Pub. 476, p. 215, pl. 6, figs. 1, 5; pl. 7, fig. 2, 1938; Axelrod, Carnegie Inst. Wash. Pub. 553, p. 281, pl. 48, fig. 4, 1944; Axelrod, Carnegie Inst. Wash. Pub. 590, p. 199, pl. 4, fig. 6, 1950; Axelrod, Univ. Calif. Pub. Geol. Sci., vol. 33 , p. 282, pl. 6, fig. 9 ; pl. 13, figs. 1-2, 1956.

The leaves of this cottonwood are so abundant at the Verdi locality they account for over 90 per cent of all the specimens examined. They are regularly small and oval to ovate, or suborbicular, like leaves produced by the living Populus trichocarpa Torrey \& Gray in the warmer parts of its range at low to moderate elevations in south-central and southern California. The related $P$. eotremuloides Knowlton, which is common in the Miocene floras of the far West, has much larger, lanceolate leaves, and they resemble those produced by the living black cottonwood in the more humid and cooler sections of its range.

Occurrence.-Verdi, Nev.: U.C. Mus. Pal. (loc. P102), hypotypes nos. 1979, 1982-1990, 2024.

\section{Populus pliotremuloides Axelrod}

(Pl. 22, figs. 5-8)

Populus pliotremuloides Axelrod, Carnegie Inst. Wash. Pub. 476, p. 168, pl. 4, figs. 1-3, 1937; Axelrod, Carnegie Inst. Wash. Pub. 553, p. 281, pl. 48, fig. 6, 1944 ; Axelrod, Carnegie Inst. Wash. Pub. 590, p. 53, pl. 2, fig. 4, 1950; Axelrod, Univ. Calif. Pub. Geol. Sci., vol. 33, p. 284, pl. 25, fig. 10, 1956.

The small characteristic leaves of aspen are rather common in the Verdi flora. They are typically oval to orbicular, with margins ranging from entire to finely crenate. The leaves of $P$. subwashoensis, which may be confused with them, differ in having relatively larger and fewer dentate teeth.

Occurrence.-Verdi, Nev.: U.C. Mus. Pal. (loc. P102), hypotypes nos. 19982001; homeotypes nos. 2002-2004.

\section{Populus subwashoensis Axelrod}

(Pl. 22, figs. 1-4)

Populus subwashoensis Axelrod, Univ. Calif. Pub. Geol. Sei., vol. 33, p. 284, pl. 6, figs. 1-4; pl. 13 , figs. 3-4; pl. 18, fig. 5, 1956.

Populus pliotremuloides Axelrod. Chaney, Carnegie Inst. Wash. Pub. 476, p. 214, pl. 6, fig. 4; pl. 7, figs. 1c, $1 d, 1938$.

Populus washoensis Brown. Axelrod, Carnegie Inst. Wash. Pub. 553, p. 131, 1944.

The small leaves of this poplar are relatively common in the Verdi flora. The leaf margins are characterized by large dentate teeth as compared with $P$. pliotremuloides, which ranges from entire to finely crenate.

Among living species, $P$. subwashoensis resembles the smaller leaves of $P$. grandidentata Michaux of the nortleastern United States and adjacent Canada. However, leaves of the cast Asian P. tremula davidiana Schneider, which ranges 
from Manchuria and Japan southward into the ligh mountains of Yumman, are regularly the small size of the fossil, and thus seem to more nearly represent its closest modern counterpart. The leaves of $P$. tremula and $P$. grandidentata both closely resemble those of $P$. washoensis, which is probably ancestral to $P$. subwashoensis.

Since the poplar and aspen leaves described from the Mulholland and Deschutes flora are similar to the Verdi material, and to leaves of the living P. tremula davidiana, they are herewith transferred to P. subwashoensis.

Occurrence.-Verdi, Nev.: U.C. Mus. Pal. (loc. P102), hypotypes nos. 20052008 ; homeotypes nos. 2009, 2010.

\section{Salix boisiensis H. V. Smith}

(Pl. 22, figs. 10-12)

Salix boisiensis H. V. Smith, Amer. Mid. Nat., vol. 25, p. 498, pl. 2, fig. 3 ; pl. 4, fig. 8, 1941 ; Axelrod, Carnegie Inst. Wash. Pub. 553, p. 194, pl. 36, figs. 8-10, 1944.

Two obovate leaf impressions in the Verdi collection are similar to the specimens of Salix boisiensis in the Thorn Creek and Sonoma floras. Like them, the Verdi leaves show relationship to those produced by the living S. scouleriana Barratt (= S. nuttallii Sargent). This is a common willow in the Sierra Nevada, ranging northward to Alaska and eastward through the Rocky Mountains.

Occurrence.-Verdi, Nev.: U.C. Mus. Pal. (loc. P102), hypotypes nos. 2011, 2012.

\section{Salix truckeana Chaney \\ (Pl. 22, figs. 9-11; pl. 23, figs. 1-3)}

Salix truckeana Chaney, Carnegie Inst. Wash. Pub. 553, p. 316, pl. 52, figs. 2-6, 1944; Axelrod, Univ. Calif. Pub. Geol. Sei., vol. 33, p. 286, pl. 26, figs. 2, 1956.

The leaf impressions of this black willow are well represented in the Verdi flora. Among living species, close relationship is apparent with leaves of Salix gooddingii Ball of central and southern California and the southwestern United States. All these areas have milder winters than those now found in western Nevada.

Occurrence.-Verdi, Nev.: U.C. Mus. Pal. (loc. P102), cotypes nos. 1991-1993; hypotypes nos. 1995-1997; homeotype no. 1994.

\section{Family FAGACEAE \\ Quercus prelobata Condit}

(Pl. 23, fig. 10)

Quercus prelobata Condit, Carnegie Inst. Wash. Pub. 553, p. 43, pl. 7, figs. 3, 4, 1944.

A fragmentary impression of a white oak leaf in the Verdi collection at the U.S. National Museum is well within the range of variation of the Remington Hill Q. prelobata Condit. Like that material, the Verdi specimen resembles leaves of the common California white oak, Q. lobata Nee. Q. utahensis (DeCandolle) Rydberg of the southern Rocky Mountain region also has similar leaves.

Occurrence.-Verdi, Nev.: U.S. National Museum. 


\section{Quercus renoana n. sp.}

(Pl. 23, figs. 4-6)

Description.-Leaves ranging from oval to oblong; tips rounded to acute, bases subrounded to truncate; length from 2.5 to $4.0 \mathrm{~cm}$., width from 1.0 to $2.0 \mathrm{~cm}$.; petiole heavy, ranging from 2 to $4 \mathrm{~mm}$. in length; midrib stout below, tapering above, and relatively straight; 9 to 11 subparallel secondaries in oval and oblong leaves, fewer in subsinuate leaf, diverging at moderate angles, looping evenly upward along margin; tertiaries comparatively coarse, trending nearly normal to secondaries at point of departure, but then becoming somewhat branching and irregular; finer mesh generally quadrangular or polygonal; margin entire to subsinuate; texture heavy.

Discussion.-Three leaf impressions in the flora resemble those produced by the living $Q$. engelmannii Greene of interior southern California, and $Q$. oblongifolia Torrey of the southwestern United States and adjacent Mexico. The finer details of nervation are similar, and close relationship is apparent in the variation in shape, which ranges from long-oval to oblong, and in the margin, which varies from entire to subsinuate. In addition, the rather numerous, essentially subparallel secondaries in the long oval leaves are like those of the living species, as is the venation of the subsinuate leaf.

Since there is considerable overlap in the leaf characters of some species of living live oaks, the question may well be raised as to whether this material really represents a new fossil oak. The leaves of Quercus convexa Lesquereux partly overlap the range of variation of these fossils, though in the large suite of material of $Q$. convexa at Table Mountain none is subsinuate. The same may be said of $Q$. dayana Knowlton, which is related to $Q$. convexa, though differing from it in that its norm of variation is toward ovate leaves, not typically long-oblong and often nearly linear-oblong ones.

Quercus convexa and $Q$. dayana have been compared with $Q$. virginiana Miller and its close relatives. There are resemblances, yet the differences are also pronounced, chiefly the tendency of the secondaries in the fossils to be essentially subparallel, whereas those of the virginiana phylad tend to depart at somewhat varying angles, and at lower angles. In addition, the secondaries of the virginiana group are more irregular, and the nervilles make a finer mesh. Thus, although $Q$. dayana and $Q$. convexa are no doubt closely related oaks, their exact relations to the modern virginiana phylad are not wholly clear. $Q$. convexa has also been compared with $Q$. oblongifolia and $Q$. engelmannii, though the range of variation does not include the sinuate and occasionally toothed leaves. However, the entire oblong leaves of $Q$. convexa appear to match the similar leaves of $Q$. engelmannii and oblongifolia more closely than those of virginiana in finer nervation and in the features of the subparallel secondaries and relatively strong intersecondaries.

Since the virginiana and engelmannii plyylads are related, it is possible that $Q$. convexa and $Q$. dayana may not bear a direct ancestral relationslip to the living types, but may well represent offshoots that ended without further issue. The limited evidence available suggests that $Q$. renoana, a member of this group, is more nearly related to engelmannii than is $Q$. convexa or $Q$. dayana. It is apparent that until more fossil material becomes available for study, the interrelationships of these fossil and living oaks will continue to remain obscure.

Occurrence.-Verdi, Nev.: U.C. Mus. Pal. (loc. P102), cotypes, nos. 2013-2015. 


\title{
Quercus wislizenoides Axelrod
}

(Pl. 23, figs. 7-8)

Quercus wislizenoides Axelrod, Carnegie Inst. Wash. Pub. 553, p. 136, pl. 29, figs. 4-9, 1944; Axelrod, ibid., p. 162, pl. 33, figs. 2, 5, 1944; Axelrod, Carnegie Inst. Wash. Pub. 590, p. 205, pl. 5, fig. 5, 1950 ; Axelrod, Univ. Calif. Publ. Geol. Sci., vol. 33, p. 291, pl. 14, figs. 1-2 ; pl. 20, figs. $4-5,8$; pl. 27 , figs. $5-8,1956$.

Impressions of two live oak leaves in the Verdi flora can be matched by leaves of the living Quercus wislizenii DeCandolle in size and shape, and also in details of venation. The leaves of $Q$. hannibali Dorf, which is related to $Q$. chrysolepis Liebmann, also show a general relationship to the fossils. However, the wavering character of the secondaries in the fossils, as contrasted with the relatively straight and subparallel secondaries in $Q$. hannibali, indicates their affinity is with the living Q. wislizenii. Although the details of finer nervation are not well preserved, there is no evidence of essentially subparallel relatively heavy tertiaries, a feature that serves to characterize $Q$. hannibali; by contrast, the tertiaries of the fossils are apparently irregular, like those of $Q$. wislizenoides.

Occurrence.-Verdi, Nev.: U.C. Mus. Pal. (loc. P102), hypotypes nos. 2016, 2017.

\section{FAMILY NAIADACEAE \\ Potamogeton verdiana $n$. sp.}

\author{
(Pl. 17, fig. 1)
}

Description.-Leaves narrow, long, and linear; total length unknown, but up to $4.0 \mathrm{~cm}$. preserved; base narrowly cuneate, tip not seen; width varying from 3.0 to $4.0 \mathrm{~mm}$. ; midrib comparatively firm, paralleled by 2 to 3 thin secondaries; tertiaries relatively prominent, widely spaced, forming crossties with the secondaries that diverge at moderate angles or nearly crosspercurrent; margin entire; texture thin.

Discussion.-Impressions of pondweed occur by the hundreds on the slabs of finely laminated diatomite that occur interbedded in the sandstone-shale section at the Verdi locality. These sediments apparently accumulated in small ponds on the Verdi floodplain, sites that probably closely resembled modern ponds where pondweed is commonly represented today. Such modern species as $P$. compressus and $P$. latifolius show relationship to the fossil species, as do others.

Occurrence.-Verdi, Nev.: U.C. Mus. Pal. (loc. P'102), holotype 110.1980 ; homeotype no. 1981.

\section{FAMILY NYMPHAEACEAE}

\section{Nymphaeites nevadensis (Knowlton) Brown}

(Pl. 23, fig. 9)

Nymphaeites nevadensis (Knowlton) Brown, Jour. Wash. Acad. Sci., vol. 27, p. 509, pl. 1, fig. 10, 1938 (see synonymy).

The characteristic rootstock impressions of $N^{\prime} y m p h a e a$ are represented in the Verdi collection at the U.S. National Museum. Their occurrence in the section indicates the presence of shallow, ponded water-bodies on the Verdi floodplain, a conclusion in harmony with the nature of the sediments.

Occurrence.-Verdi, Nev.: U.S. National Museum. 


\section{FAMILY GROSSULARIACEAE}

\section{Ribes galeana n. sp.}

(Pl. 23, fig. 14)

Description.-Leaf deeply 3-lobed, the lobes widening above; base subcordate; leaf blade 1.2 $\mathrm{cm}$. long and $1.4 \mathrm{~cm}$. wide; petiole thin, $8 \mathrm{~mm}$. long; midrib thin, eurved below and thinner above; 2 main primaries from the top of the petiole on one side of the blade, and one primary and a strong tertiary on the other; a strong secondary diverging at $70^{\circ}$ from each side of the midrib near its center, and supplying the uppermost 2 lateral lobes, which are rounded at the apex, secondaries entering the uppermost lobes of the central lobe from near the apex; several tertiaries departing along the midrib; finer nervation irregular and coarse; margin entire, the apices of the lobes notched; texture thin-medium.

Discussion.-This leaf and its counterpart appear to represent gooseberry rather than currant. There is so much overlap in the leaf variation of the living species that it is not possible to single out any one as the closest counterpart of the fossil. It is perhaps sufficient to note that the fossil leaf is very similar to those produced by the living Ribes (Grossularia) roezlii Regel, a common shrub in western Nevada and California.

This species is named for Hoyt S. Gale, who, in the summer of 1914, made the small but significant collection of Verdi plants now in the U.S. National Museum.

Occurrence.-Verdi, Nev.: U.C. Mus. Pal. (loc. P102), holotype no. 2018.

\section{FAMILY ROSACEAE}

\section{Prunus moragensis Axelrod}

$$
\text { (Pl. 23, figs. 11-13) }
$$

Prunus moragensis Axelrod, Carnegie Inst. Wash. Pub. 553, p. 140, pl. 30, figs. 6, 8, 10, 1944 ;

Axelrod, Univ. Calif. Pub. Geol. Sei., vol. 33, p. 301, pl. 28, fig. 15, 1956.

Two long-oval leaf impressions with finely serrate margins and thin, looping secondaries, are similar to leaves produced by the living Prunus emarginata (Douglas) Walpers. In addition, an impression of a broadly oval nut resembles those formed by the living bitter cherry, and is therefore assigned to the same species. Bitter cherry is widely distributed in the western United States, chiefly in the montane forest and on its margins, where it commonly forms dense thickets on stream banks and in moist swales.

Occurrence.-Verdi, Nev.: U.C. Mus. Pal. (loc. P102), hypotypes nos. 20192021.

\section{FAMiLy RHAMNACEAE}

\section{Ceanothus precuneatus Axelrod}

(Pl. 23, fig. 17)

Ceanothus precuneatus Axelrod, Carnegie Inst. Wash. Pub. 476, p. 120, pl. 11, fig. 7, 1939; Axelrod, Carnegie Inst. Wash. Pub. 553, p. 261, pl. 45, figs, 2, 3, 1944 ; Axelrod, Carnegie Inst. Wash. Pub. 590, p. 153, pl. 3, fig. 15, 1950; Axelrod, Univ. Calif. Pub. Geol. Sci., vol. 33, p. 308, pl. 32, fig. 8, 1956.

$\Lambda \mathrm{n}$ impression of a coriaceous, obovate leaf with thin, subparallel secondaries diverging into the upper part of the blade, appears referable to this species. It 
resembles leaves produced by the living Ceanothus cuneatus Nuttall, which is a chaparral dominant in central and southern California. The shrub also oceurs seattered in openings and on drier sites throughout the lower part of the yellow pine forest on the west slope of the range.

Occurrence.-Verdi, Nev.: U.S. Nat. Museum.

\section{FAMILY ERICACEAE \\ Arctostaphylos verdiana $n$. sp.}

(Pl. 23, figs. 15-16)

Description.-Leaves obovate to oral, tips acute to subacuminate, bases cuneate to acute; 1.5 to $2.0 \mathrm{~cm}$. long and $7 \mathrm{~mm}$. to $1.2 \mathrm{~cm}$. wide; petiole 3 to $4 \mathrm{~mm}$. long, heavy; midrib straight and stout, becoming thin above; alternate secondaries departing at low angles, the lower pairs reaching well upward into the upper part of the blade; tertiaries irregular; margin entire; texture thick.

Discussion.-These carbonized impressions resemble leaves produced by the living Arctostaphylos nevadensis Gray, a sprawling shrub that is common throughout the Sierra Nevada and higher North Coast Ranges in the middle to upper parts of the pine-fir forest. The only other fossil manzanita resembling this species is Arctostaphylos cuneata Brown from Salmon, Idaho (Brown, 1935, pl. 67, fig. 20). It differs from $A$. verdiana in having a typically rounded, rather than an acute tip. Among living species $A$. cuneata appears to be more nearly related to $A$. $u v a$ ursi Sprengel than to $A$. nevadensis.

Occurrence.-Verdi, Nev.: U.C. Mus. Pal. (loc. P102), holotype no. 2022, paratype no. 2023. 


\section{LITERATURE CITED}

Anderson, R. A.

1909. Geology and oil prospects of the Reno region, Nevada. U.S. Geol. Surv. Bull. 381, pp. $475-489$.

Axelrod, Daniel I.

1937. A Pliocene flora from the Mount Eden beds, southern California. Carnegie Inst. Wash. Pub. 476, pp. 125-183.

1938. The stratigraphic significance of a southern element in later Tertiary floras of western America. Jour. Wash. Acad. Sei., vol. 28, pp. 314-322.

1940. The Pliocene Esmeralda flora of west-central Nevada. Jour. Wash. Acad. Sci., vol. 30, pp. $163-174$.

1941. The concept of ecospecies in Tertiary paleobotany. Proc. Nat. Acad. Sei., vol. 27, pp. 545-551.

1944a. The Mulholland flora (California). Carnegie Inst. Wash. Pub. 553, pp. 103-146.

1944b. The Oakdale flora (California). Carnegie Inst. Wash. Pub. 553; pp. 147-165.

1944c. The Sonoma flora (California). Carnegie Inst. Wash. Pub. 553, pp. 167-206.

1944d. The Pliocene sequence in central California. Carnegie Inst. Wash. Pub. 553, pp. 207224.

1944e. The Alvord Creek flora (Oregon). Carnegie Inst. Wash. Pub. 553, pp. 225-262.

1944 $f$. The Alturas flora (California). Carnegie Inst. Wash. Pub. 553, pp. 263-284.

1948. Climate and evolution in western North America during Middle Pliocene time. Evol., vol. 2, pp. 127-144.

1949a. Eocene and Oligocene formations in the western Great Basin (abstract). Bull. Geol. Soc. Amer., vol. 60, pp. 1935-1936.

1949b. Discussion of: Sedimentary facies in geologie history. Geol. Soc. Amer., Memoir 39, pp. 155-164.

1950a. A Sonoma florule from Napa, California. Carnegie Inst. Wash. Pub. 590, pp. 23-71.

1950b. The Anaverde flora of southern California. Carnegie Inst. Wash. Pub. 590, pp. 119-158.

1950c. The Piru Gorge flora of southern California. Carnegie Inst. Wash. Pub. 553, pp. 159214.

$1950 d$. Evolution of desert vegetation in western North America. Carnegie Inst. Wash. Pub. 590, pp. 215-360.

1956. Mio-Pliocene floras from west-central Nevada. Univ. Calif. Publ. Geol. Sei., vol. 33, pp. $1-322$.

1957a. Late Tertiary floras and the Sierra Nevadan uplift. Bull. Geol. Soe. Amer., vol. 68, pp. $19-46$.

1957b. Age-curve analysis of angiosperm floras. Jour. Paleo., vol. 31, pp. 273-280.

BARGHOORN, E. S.

1951. Age and environment: a survey of North American Tertiary floras in relation to paleoeeology. Jour. Paleo., vol. 25, pp. 736-744.

Brown, R. W.

1935. Miocene leaves, fruits, and seeds from Idaho, Oregon and Washington. Jour. Paleo., vol. 9, pp. 572-587.

1937. Further additions to some fossil floras of the western United States. Jour. Wash. Acad. Sei., vol. 27, pp. 506-517.

1940. New species and changes of name in some American fossil floras. Jour. Wash. Acad. Sei., vol. 30, pp. 344-356.

BUWALDA, J. P.

1914. A proboseedian tooth from the Truckee beds of western Nevada. Univ. Calif. Publ., Bull. Dept. Geol. Sci., vol. 8, pp. 305-308.

Chaney, R. W.

1938a. The Desehutes flora of eastern Oregon. Carnegie Inst. Wash. Pub. 476, pp. 187-216. 
1938b. Paleoecological interpretations of Cenozoic plants in western North America. Bot. Review, vol. 4, pp. 371-396.

1944a. Pliocene floras of California and Oregon. Introduction. Carnegie Inst. Wash. Pub. 553, pp. 1-19.

1944b. The Dalles flora (Oregon). Carnegie Inst. Wasl. Pub. 553, pp. 285-321.

1948. The ancient forests of Oregon. Condon Lectures, Oregon State System of Higher Education. Eugewe, Oregon. $56 \mathrm{pp}$.

CoNDIT, C.

1944a. The Remington Hill flora (Califoruia). Carnegie Inst. Wash. Pub. 553, pp. 21-55.

1944b. The Table Mountain flora (California). Carnegie Inst. Wash. Pub. 553, pp. 57-90.

CuRTis, G.

1954. Mode of origin of pyroclastic debris in the Mehrten formation of the Sierra Nevada. Univ. Calif. Publ. Geol. Sci., vol. 29, pp. 453-502.

Dalei, A. C., and D. M. Poole

1949. A geologic section in East-Central California eastward from Donner Pass. M.A. thesis. Univ. of California, Los Angeles.

DORF, ErLing

1930. Pliocene floras of California. Carnegie Inst. Wash. Pub. 412, pp. 1-112.

Gianella, V. P.

1936. Geology of the Silver City district and the southern portion of the Comstock Lode, Nevada. Bull. Nev. State Bur. of Mines and Mackay School of Mines, vol. 30, no. 9, pp. 1-108.

1948. Fusion of lacustrine deposits near Verdi, Nevada. Bull. Geol. Soc. Aner., vol. 59, p. 1370. HuL, J. M.

1915. Peavine district, Washoe County, Nevada. In Some mining districts in northeastern California and northwestern Nevada. U.S. Geol. Surv. Bull. 594, pp. 184-197.

King, Clarence

1878. Geological exploration of the Fortieth Parallel. U.S. Army Engr., Prof. Paper 18. 3 vols.

LAMOTTE, R. S.

1952. Catalogue of Cenozoic plants of North America through 1950. Geol. Soc. Amer. Mem. 51. $381 \mathrm{pp}$.

LESQUerEUX, LeO

1883. Contributions to the fossil flora of the western territories. III. The Cretaceous and Tertiary floras. Rept. U.S. Geol. Surv. Terr., vol. 8.

LINDGREN, W.

1897. Description of the Truckee quadrangle. U.S. Geol. Surv., Geol. Atlas, Truckee folio (California). Folio no. 39. 8 pp.

\section{LOUDERBACK, D.}

1906. Some geologic features of the Truckee region east of the Sierra Nevada. Bull. Geol. Soc. Amer., vol. 18, pp. 622-669.

\section{MacDonald, James R.}

1950. A note on the age of the Truckee formation. Amer. Jour. Sci., vol. 248, pp. 581-583.

1956. A new Clarendonian mammalian fauna from the Truckee formation of western Nevada. Jour. Paleo., vol. 30, p. 186-202.

MacGinitie, H. D.

1953. Fossil plants of the Florissant beds, Colorado. Carnegie Inst. Wash. Pub. 599. 188 pp.

Merriam, John C.

1916. Tertiary vertebrate fauna from the Cedar Mountain region of western Nevada. Univ. Calif. Publ., Bull. Dept. Geol. Sci., vol. 9, pp. 161-198.

MerRiam, John C., and C. STOCK

1933. Tertiary mammals from the Auriferous gravels near Columbia, California. Carnegie Inst. Wash. Pub. 393, pp. 5-21. 
SMITE, H. V.

1941. A Miocene flora from Thorn Creek, Idaho. Amer. Mid. Nat., vol. 25, pp. 473-532.

StiRTon, R. A.

1939. The Nevada Miocene and Pliocene mammalian faunas as faunal units. Proc. 6 th Pacific Sei. Congr., pp. 627-640.

StiRton, R. A., and H. F. GOeriz

1942. Fossil vertebrates from the superjacent deposits near Knight's Ferry, California. Univ. Calif. Publ., Bull. Dept. Geol. Sci., vol. 26, pp. 447-472.

THOMPSON, GEORGE A.

1956. Geology of the Virginia City quadrangle, Nevada. U.S. Geol. Surv. Bull, 1042-C. 77 pp. YEN, TENG-CHIEN

1950. A molluscan fauna from the type section of the Truckee formation. Amer. Jour. Sci., vol. 248 , pp. $180-193$. 
PLATES 


\section{PLATE 13}

Views of the Verdi Locality

Fig. 1. Looking southwesterly from the basalt bluff on the north side of the Truckee River a mile east of Verdi. The plant locality is in the railroad cut marked by the arrow. Crystal Peak ridge forms the bulk of the skyline, with the Truckee River in the gorge near the left margin of the view.

Fig. 2. Locality P102. The 30 -foot section at the plant locality is made up of coarse lenticular sandstone, sandy shale, and thin diatomite. The bestpreserved fossils occur in the finer sandstones near the right-hand margin (west) of the outcrop. 

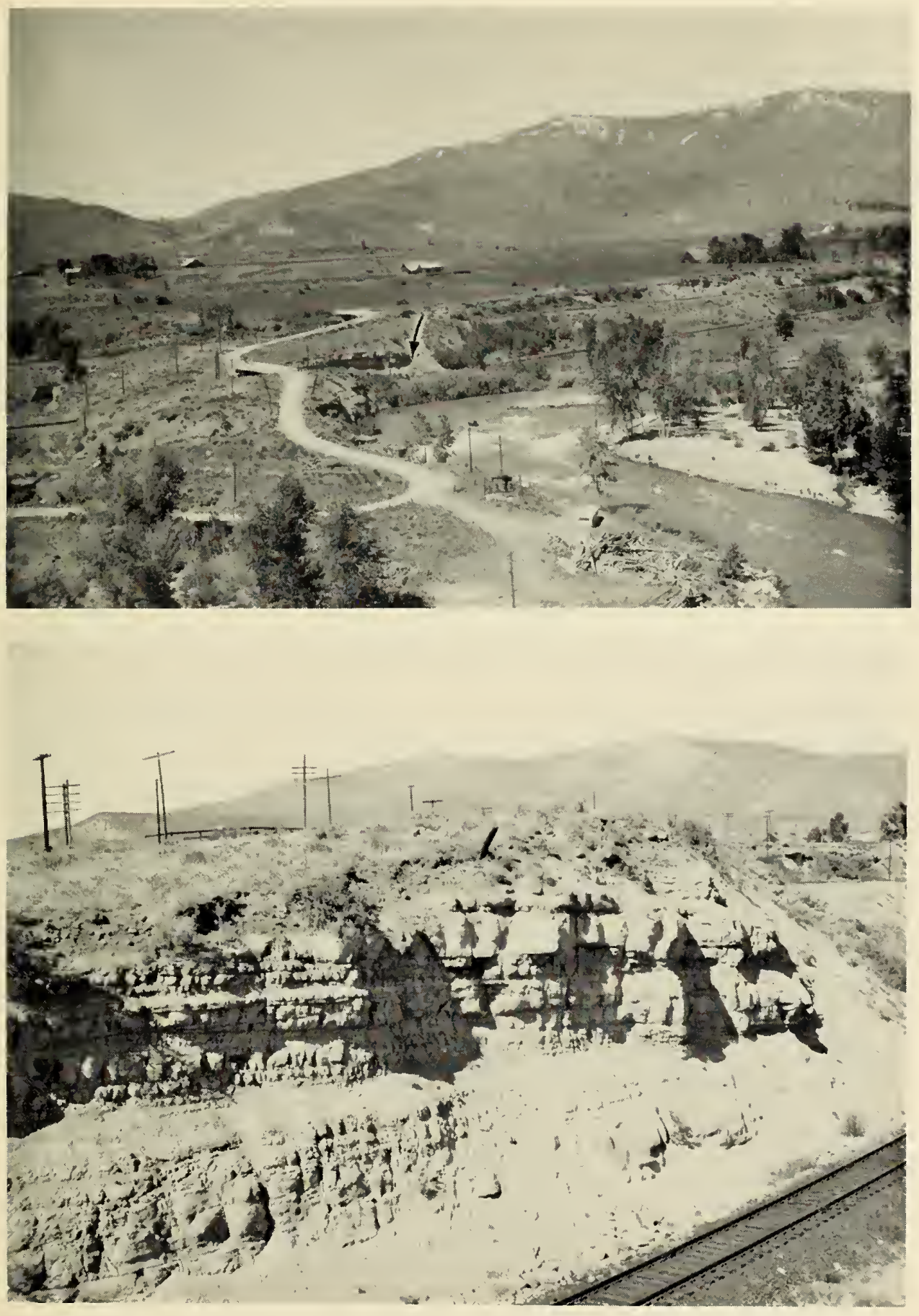


\section{PLATE 14}

Modern Vegetation Related to the Verdi Flora

Fig. 1. Looking west on State Ilighway 88 a few miles east of Jackson, California. In the foreground is a live oak woodland of Quercus lobata and $Q$. wislizenii, with associates of manzanita, buckbrush, and willow. The Sierran forest of yellow pine, white fir, sugar pine, gooseberry, and willow occurs on the cooler, south side of the valley, with tongues of forest entering the woodland in farorable sites.

Fig. 2. Looking west on State Highway 49 a few miles south of Placerville, Califormia. Oak woodland and saranna occupy the more exposed southerly sites, with the Sierran forest confined to the cooler northerly exposures (left). Most of the species represented here also occur at the locality shown in figure 1. 

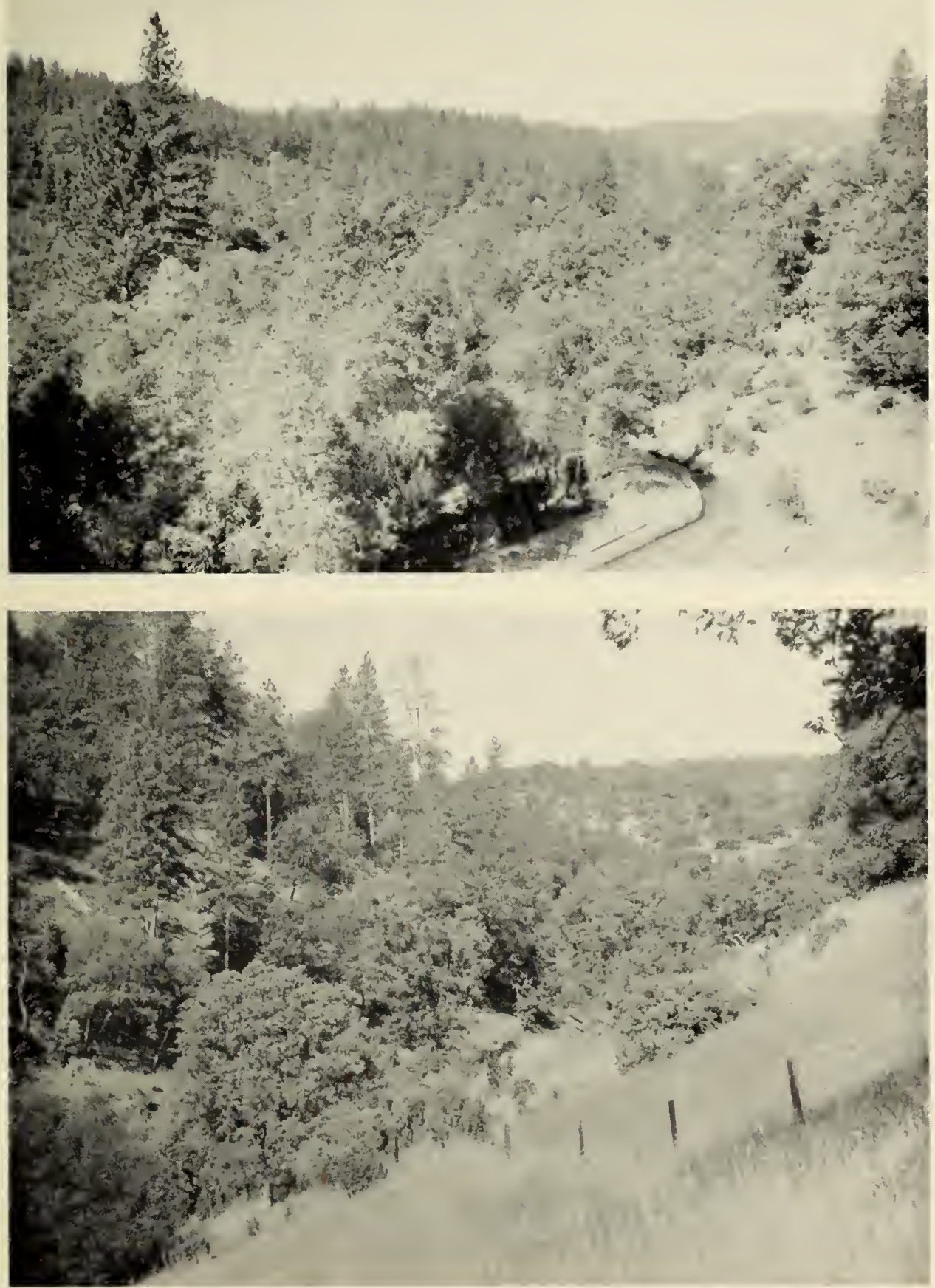
Moderu Vegetation Related to the Verdi Flora

Fig. 1. Looking westward down a tributary eanyon of the Santa Ana River, southern California. Live oaks and chaparral are in the foreground, with the Sierran forest of yellow pine, white fir, sugar pine, and their assoeiates across the eanyon.

Fig. 2. View looking northwesterly into the Santa Ana River canyon. A near view of the Sicrran forest of white fir, yellow pine, sugar pine, and their assoeiates of willow, manzanita, and cherry; aspen oceurs in the forest at higher levels; chaparral covers most of the south-facing slope across the ralley. 

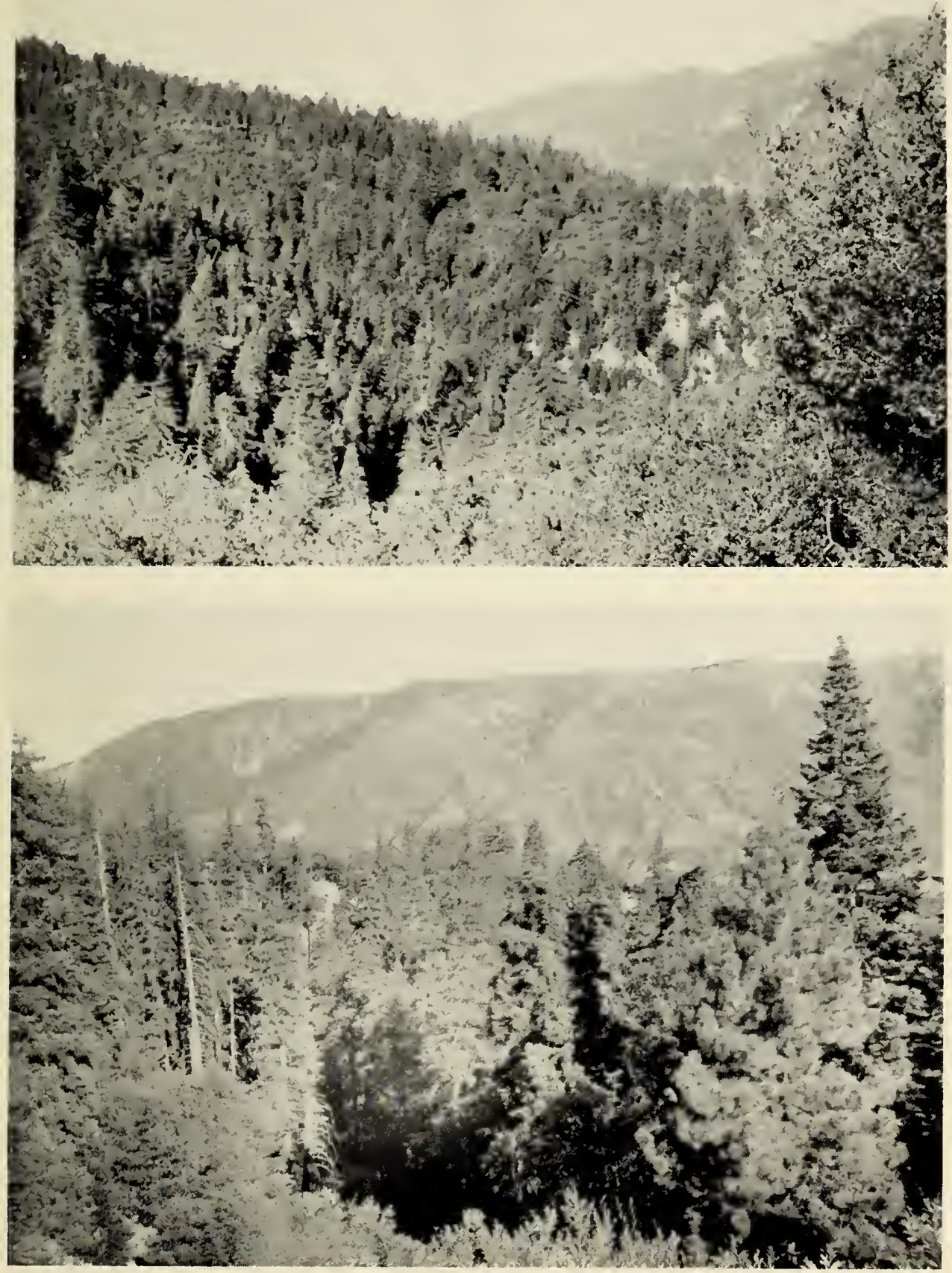
Moderu Vegetation Related to the Verdi Flora

Fig. 1. View of the Knobcone pine forest at the lower margin of yellow pine forest on the City Creek road, sonthem California. The small pines in the foreground are mingling with a chaparral composed of species of serub oak, buckbrush, and manzanita. The Sierran forest covers the upper slopes.

Fig. 2. View up the valley of Mill Creek, southern California, from an altitude of 4,500 feet. Woodland and chaparral cover the lower and middle mountain slopes to the right, with forest above. Forest reaches the floor of the canyon a short distance upstream, where species of rellow pine, white fir, sugar pine, manzanita, cherry, and willow occur which are closely smilar to Verdi plants. Cottonwood is common a short distance downstream, where its leares are small like the Verdi dominant. 

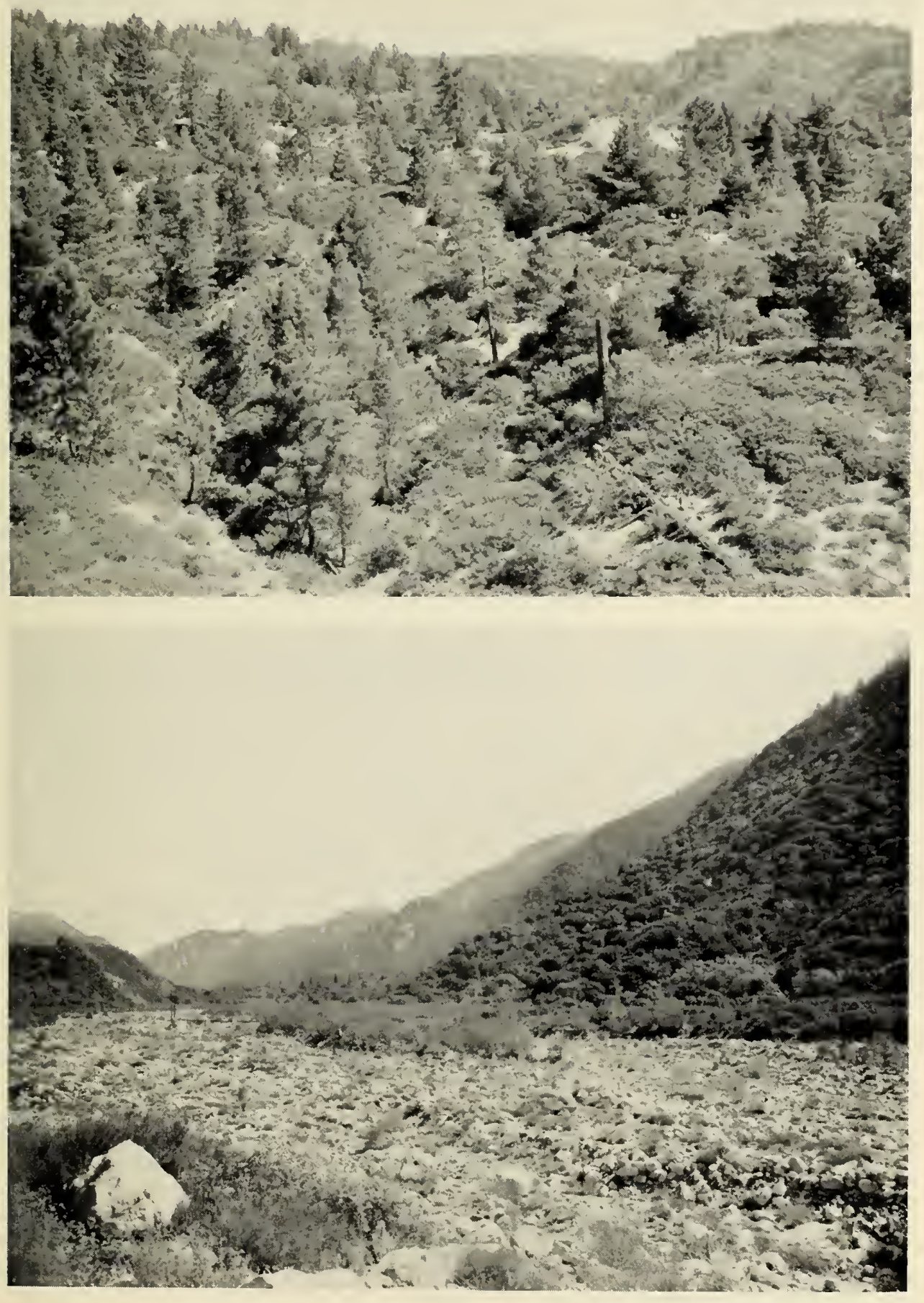


\section{PLATE 17}

Verdi Fossils

Fig. 1. Potamogeton verdiana Axelrod. Holotype, U.C. Mfus Paleobot. ser., no. 1980.

Fig. 2. Chara verdiana Axelrod. Holotype, U.C. Mus. Paleobot. ser., no. 1961.

Fig. 3. Pinus florissanti Lesquereux. Hypotype, U.C. Mus. Paleobot. ser., no. 1968. 


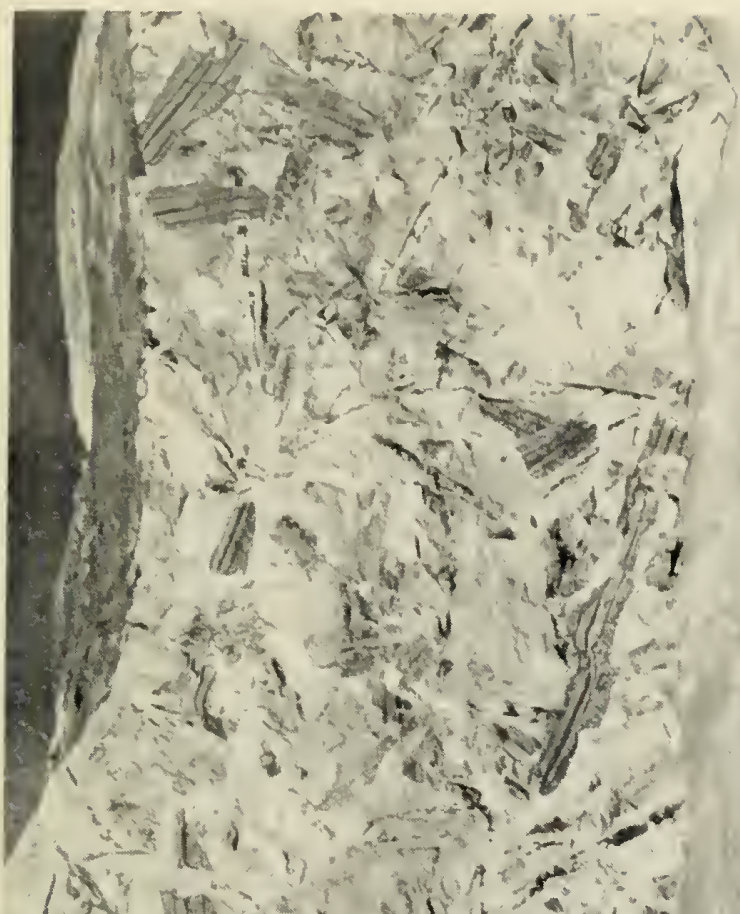

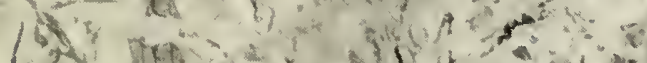

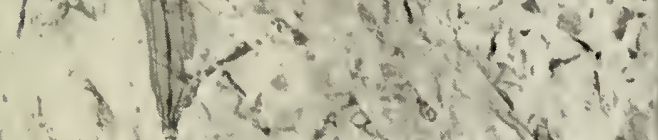

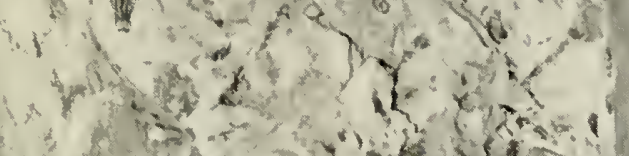

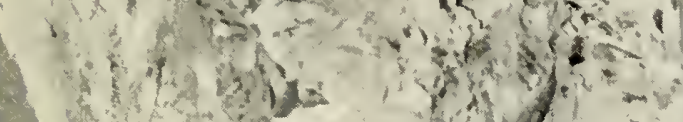

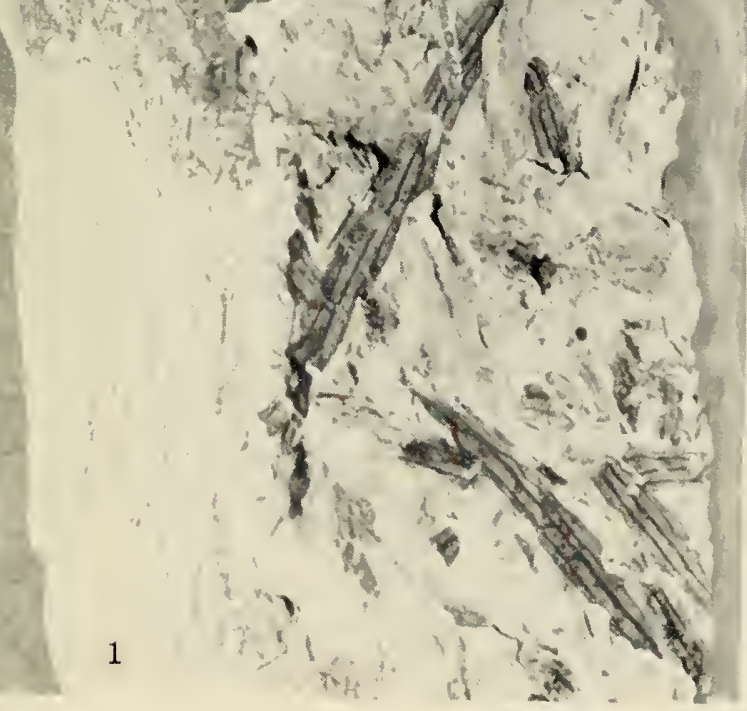

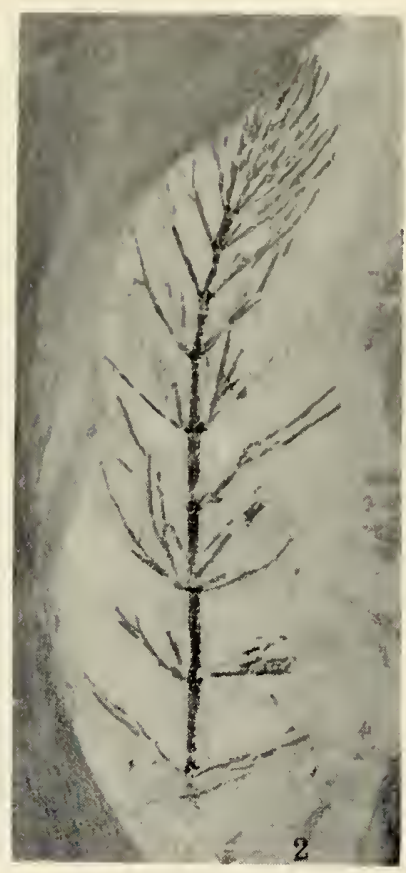

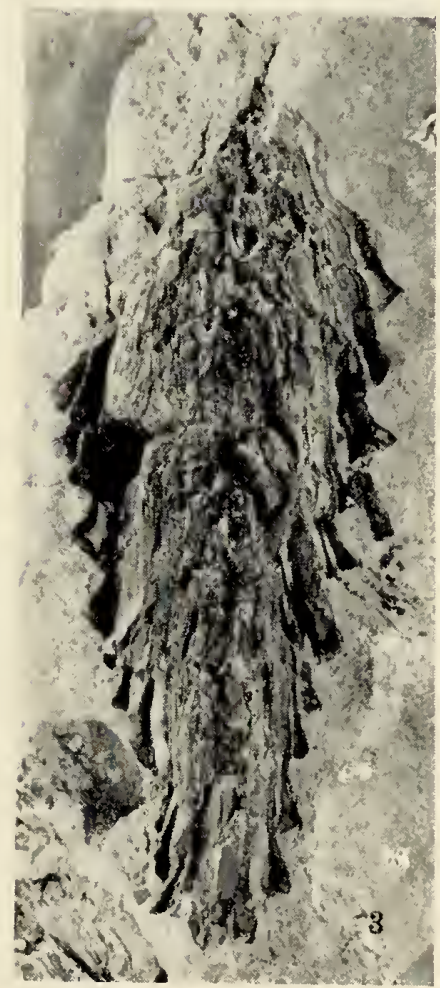




\section{PLATE 18}

Verdi Fossils

Figs. 1-2.'Abies concoloroides Bromn. Hypotypes, U.C. Mus. Paleobot, ser., nos. $1962 a, 1962$.

Figs. 3-4. Pinus pretuberculata Axelrod. Hypotypes, U.C. Mus. Paleobot. ser., nos. 1973, 1972 .

Figs. 5-6. Abies coneoloroides Brown. Hypotypes, U.C. Mrus. Paleobot. ser., nos. $1965,1963$.

Figs. 7-8. Pinus prelambertiana Axelrad. Ilypotypes, U.C. Mus. Paleobot. ser., no. 1976 (two views of the same specimen).

Figs. 9-10. Pinus prelambcrtiana Axelrod. Hypotypes, U.C. Mus. Paleobot. ser., nos. 1978, 1977 .

Figs. 11-12. Pinus pretubereulata Axelrod. Hypotypes, U.C. Mus. Paleobot. ser., nos. $1975,1974$.

Fig. 13. Pinus pretubcreulata Axelrod. IIypotype, U.S. National Museum. 

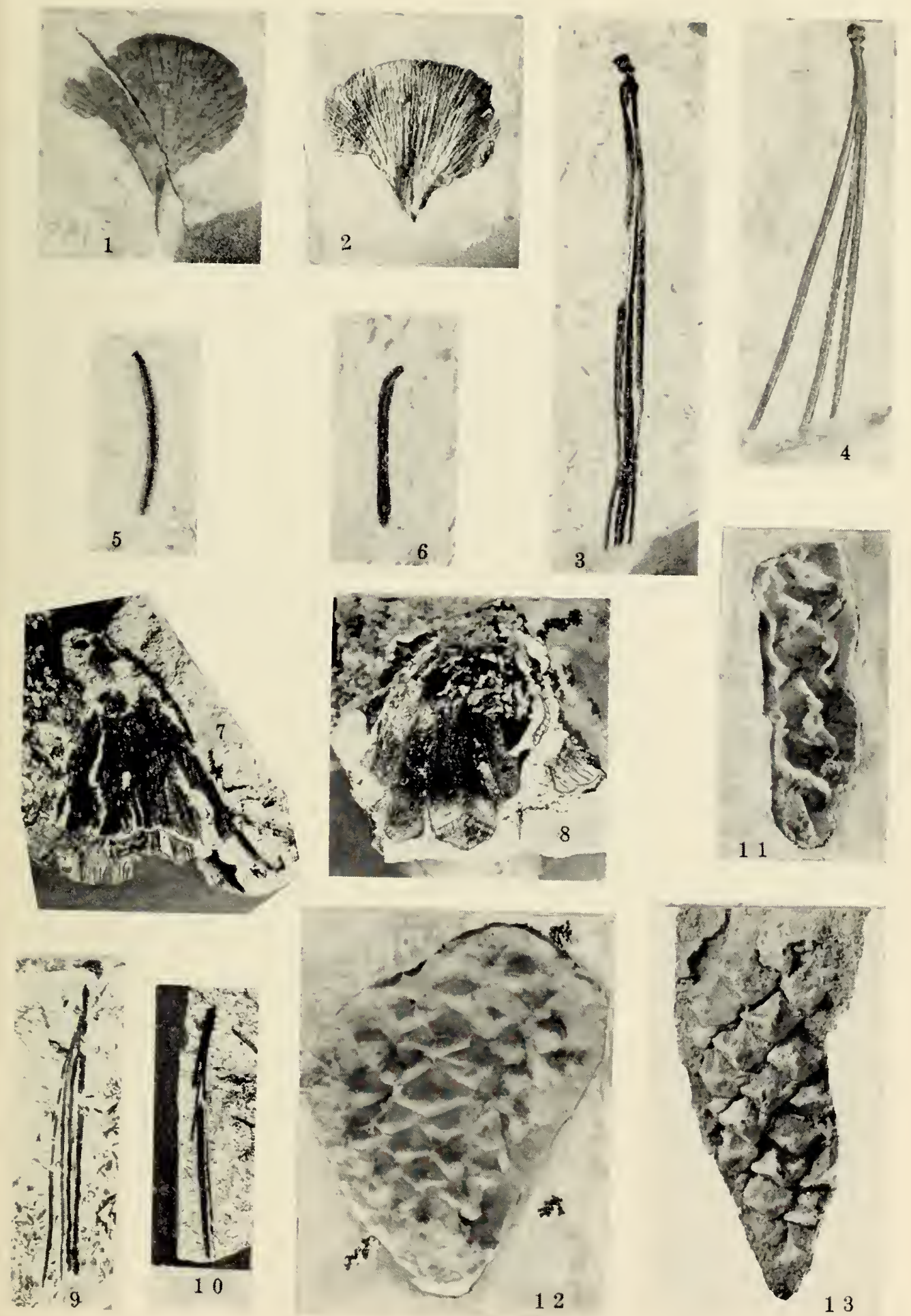
PLATE 19

Verdi Fossils

Figs. 1-4. Populus alexanderi Dorf. Hypotypes, U.C. Mus. Paleobot. ser., nos. 1984, 1979, 1986, 1983.

Figs. 5-8. Populus alexanderi Dorf. Hypotypes, U.C. Mus. Paleobot. ser., nos. $1987,1989,1990,1985$.

Figs. 9-11. Populus alexanderi Dorf. Hypotypes, U.C. Mus. Paleobot. ser., nos. $1982,2024,1988$. 

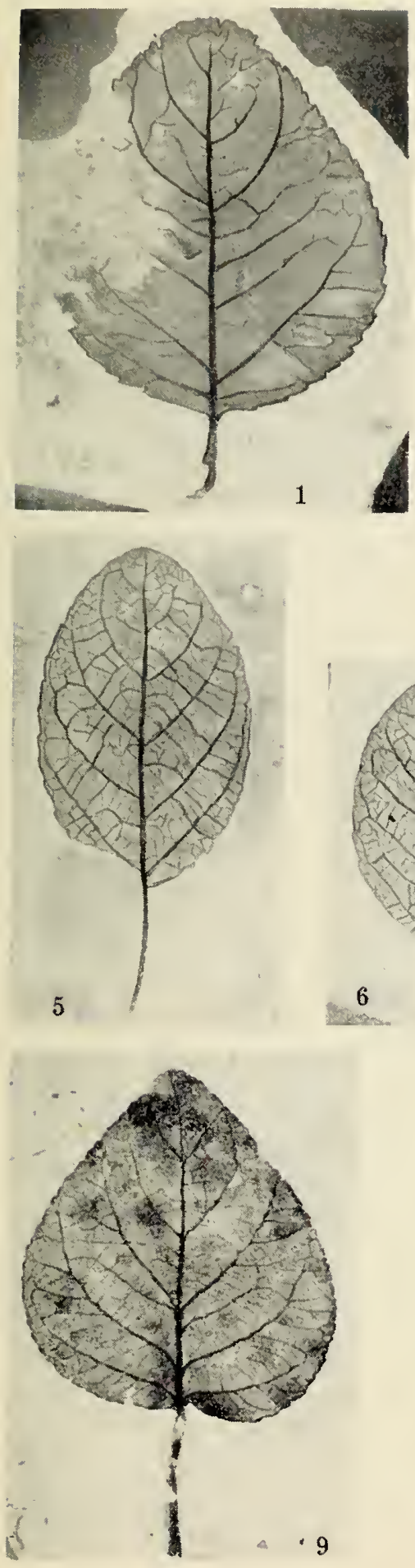
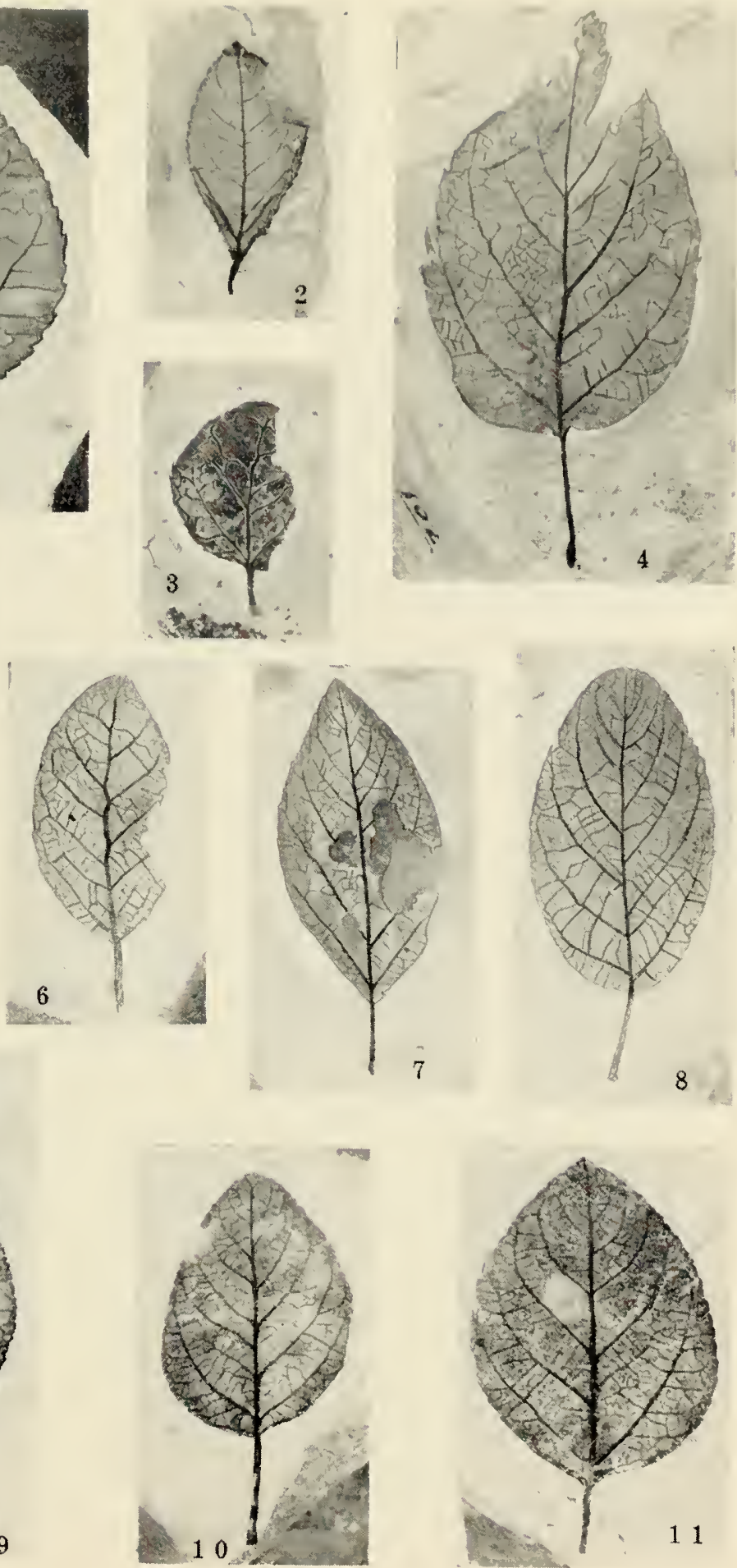


\section{PLATE 20}

Leaves of Populus trichocarpa for Comparison with Populus alexanderi Dorf

Figs. 1-3. Typical leaves of Populus trichocarpa from the Verdi region. They average much larger than the Verdi fossils, and also differ from them in shape (see pl. 19). 


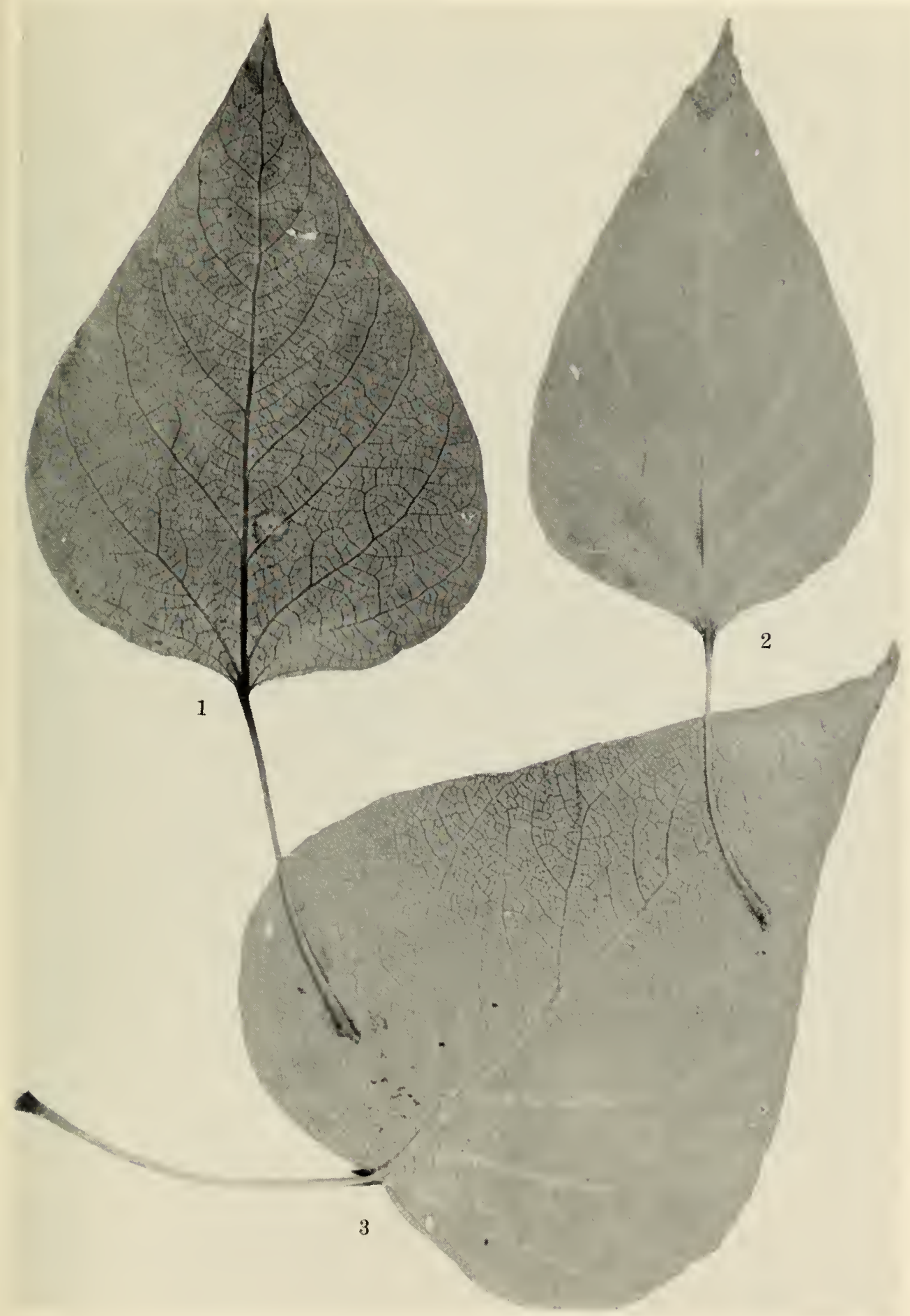

[ 153$]$ 
PLATE 21

Leares of Polulus trichocarpa for Comparison with Populus alcxanderi Dorf

Figs. 1-11. Typical leaves of Populus trichocarpa from the mountains of southern California, collected from trees below the yellow pine forest zone. They compare favorably with the leares of Populus alexanderi Dorf in the Verdi flora (see pl. 19). 


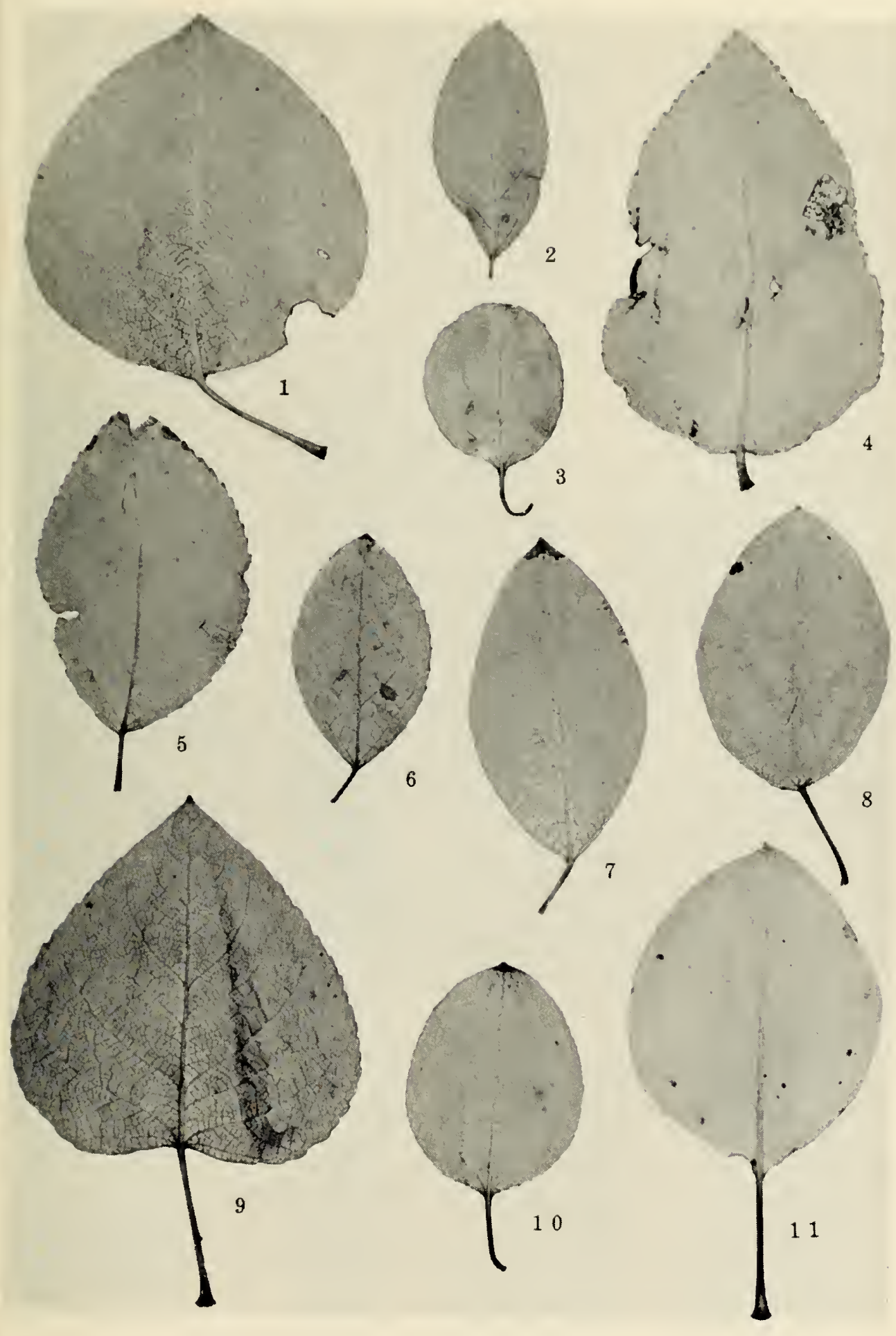

[ 155 ] 


\section{PLATE 22}

\section{Verdi Fossils}

Figs. 1-4. Populus subwashoensis Axelrod. IIypotypes, U.C. Mus. Paleobot. ser., nos. 2006, 2007, 2008, 2005.

Figs. 5-8. Populus pliotremuloides Axelrod. IIypotypes, U.C. Mus. Paleobot. ser., nos. 2000, 2001, 1998, 1999.

Figs. 9-11. Salix truckeana Chaney. Iypotypes, U.C. Mus. Paleobot. ser., nos. $1995,1996,1997$.

Figs. 12-13. Salix boisiensis Smith. IIypotypes, U.C. Mus. Paleobot. ser., nos. $2011,2012$. 

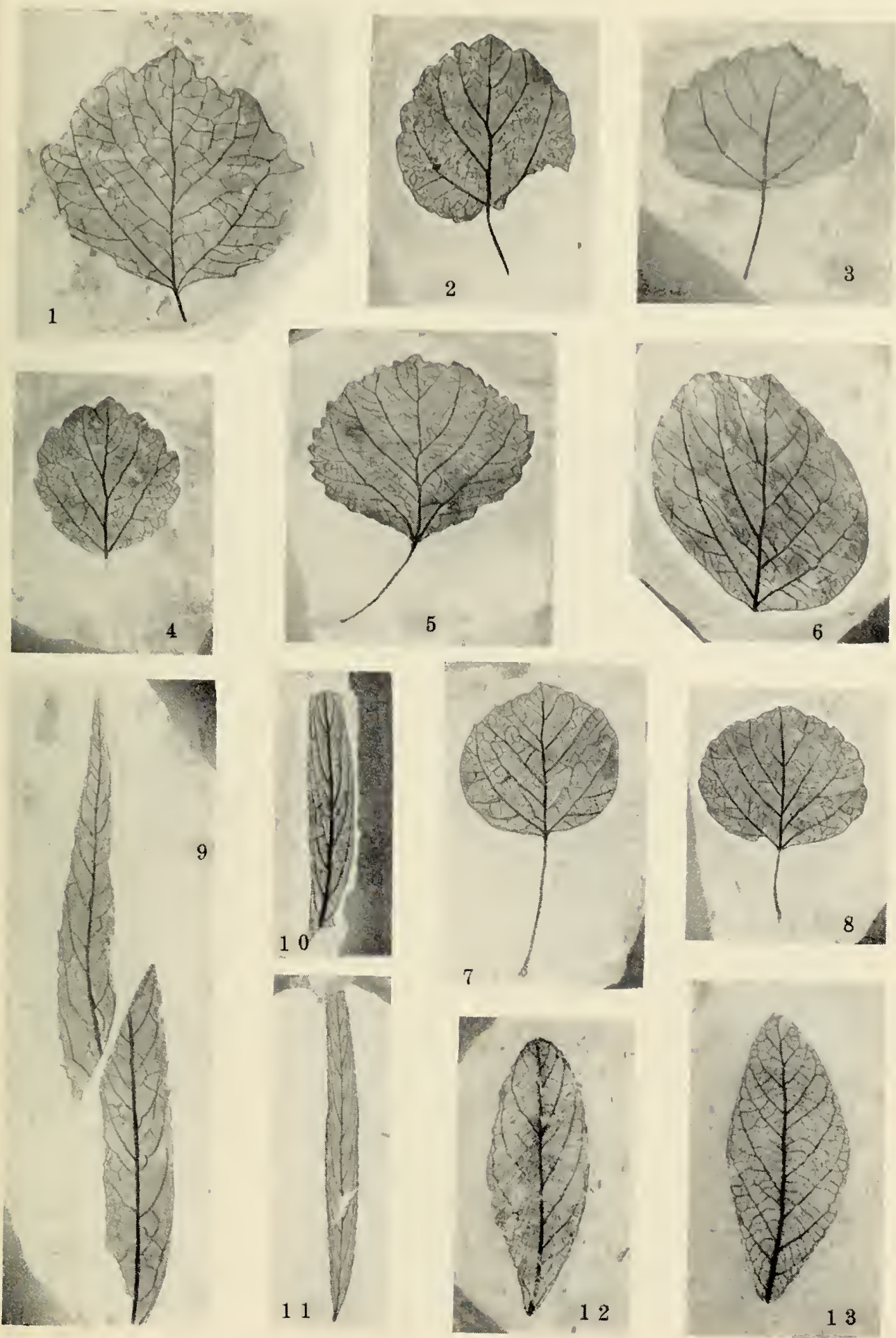


\section{PLATE 23}

Terdi Fossils

Figs. 1-3. Salix truckeana Chaney. Cotypes, U.C. Mus. Paleobot. ser., nos. $1991,1993,1992$.

Figs. 4-6. Quercus renoana Axelrod. Cotypes, U.C. Mus. Paleobot. ser., nos. $2013,2015,2014$.

Figs. 7-8. Quercus vislizenoides Axelrod. Hypotypes, U.C. Mus. Paleobot. ser., nos. 2017, 2016.

Fig. 9. Nymphacites nevadensis (Knowlton) Brown. Hypotypes, U.S. National MLuseum.

Fig. 10. Quercus prelobata Condit. Hypotype, U.S. National Museum.

Figs. 11-13. Prunus moragensis Axelrod. Hypotypes, U.C. Mus. Paleobot. ser., nos. 2021, 2019, 2020.

Fig. 14. Ribes galeana Axelrod. Holotype, U.C. Mus. Palebot. ser., no. 2018.

Fig. 15. Arctostaphylos verdiana Axelrod. Holotype, T.C. Mus. Paleobot. ser., 110.2023.

Fig. 16. Arctostaphylos verdiana Axelrod. Paratype, U.C. Mus. Paleobot. ser., no. 2022 .

Fig. 17. Ceanothus precuncatus Axelrod. Hypotype, U.S. National Museum. 

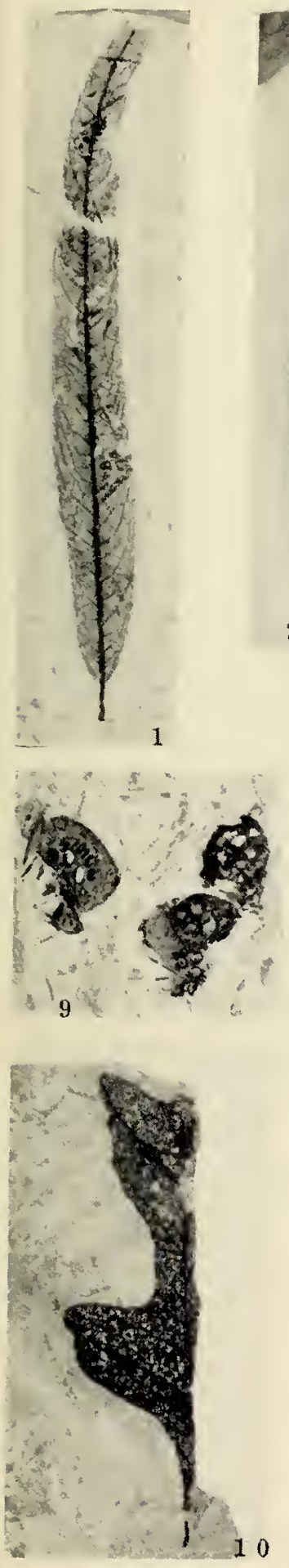
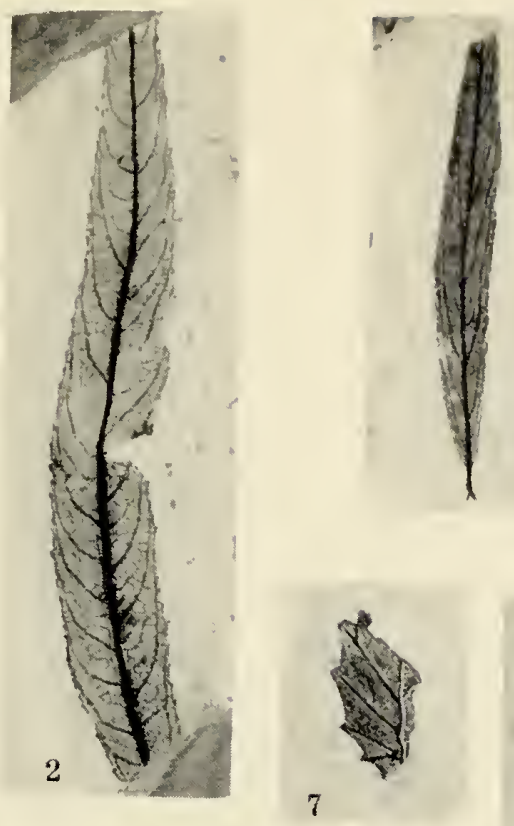

8

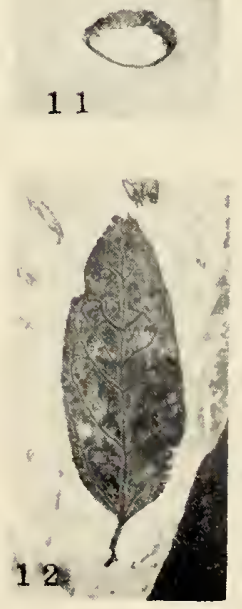

3
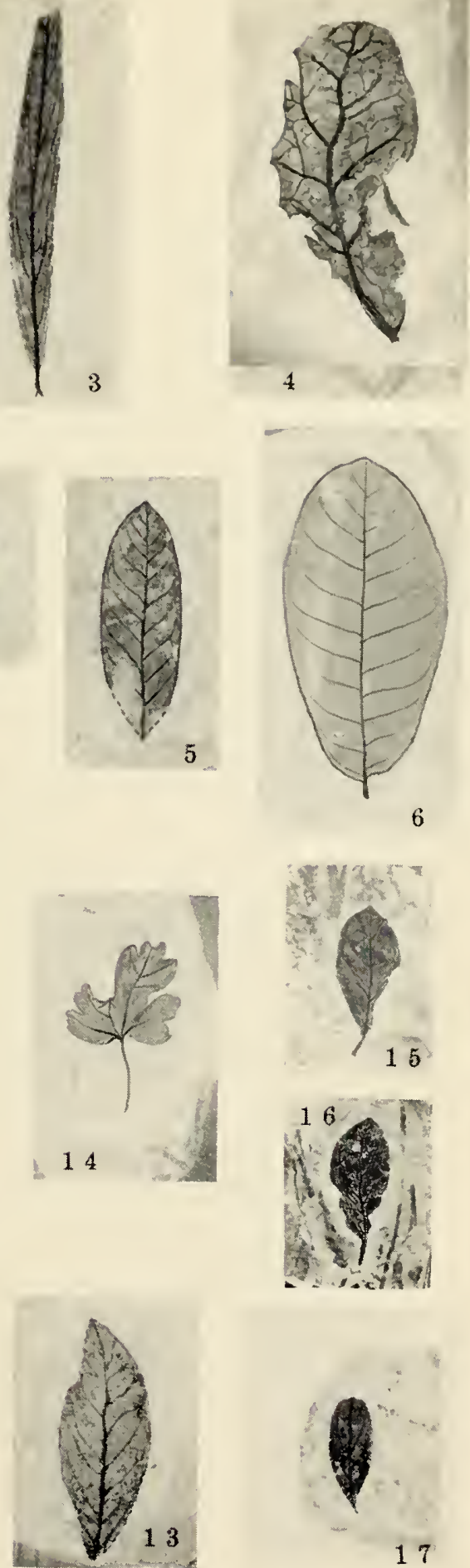
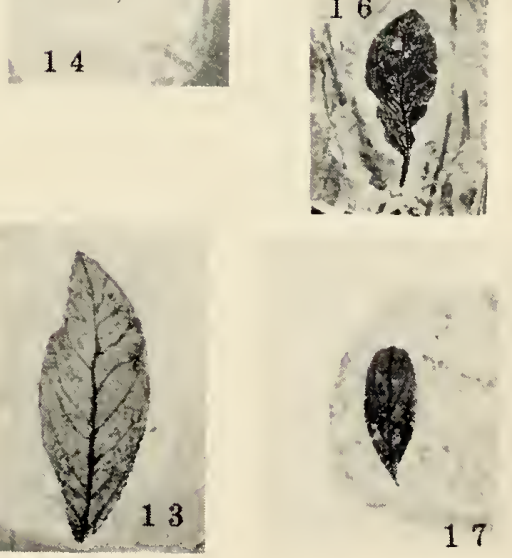
$7463 \quad 030$ 






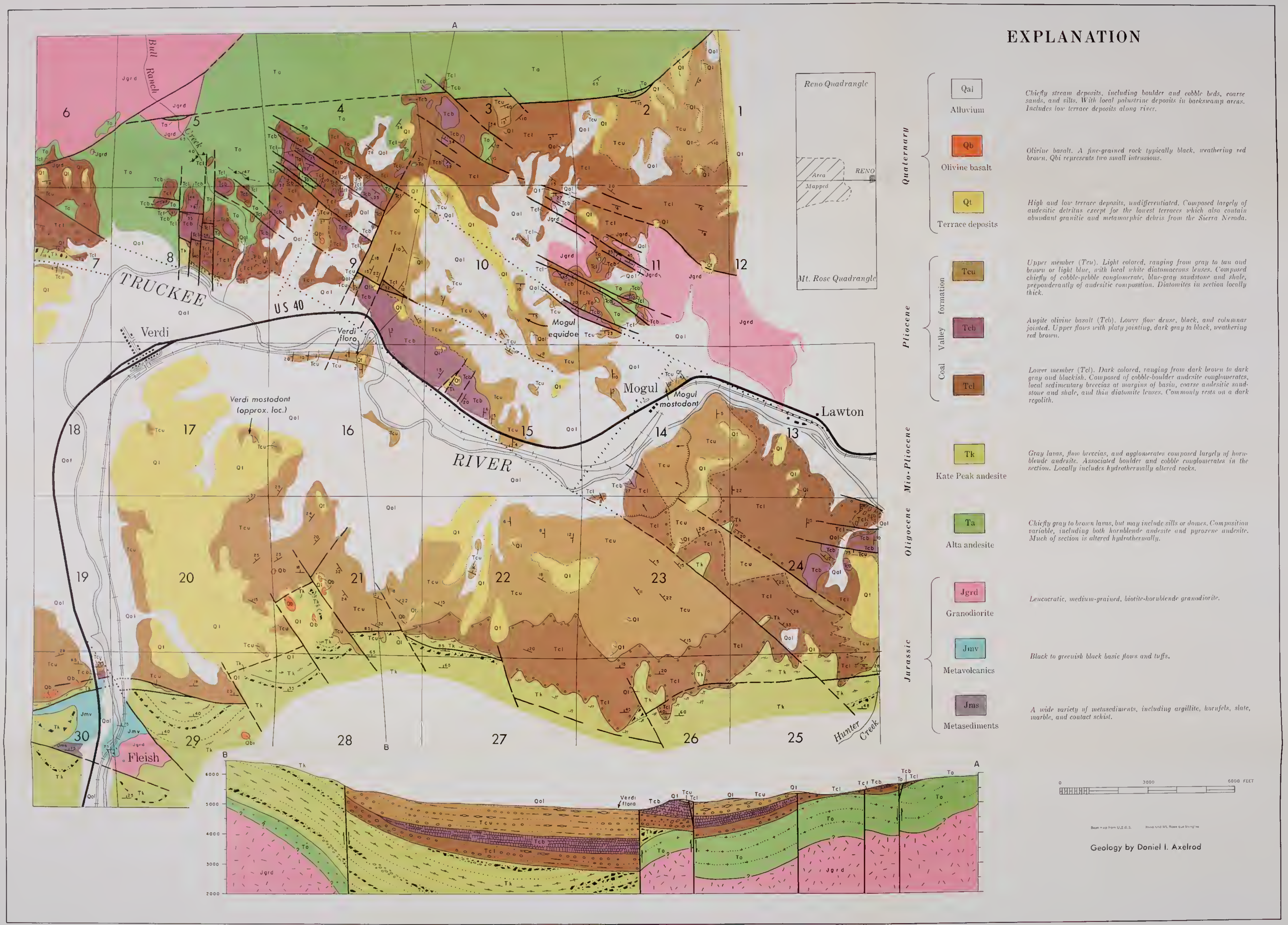


$\therefore 8$

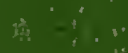

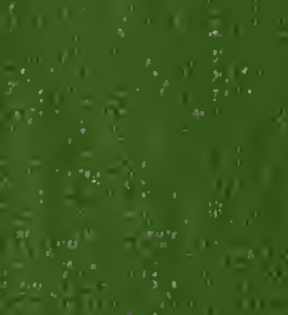

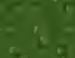

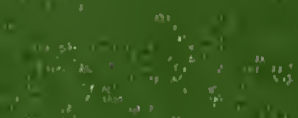

and

$4-2$

and

C.

Fin

and

$1+y^{2}$

and

a d on

(n)

(1)

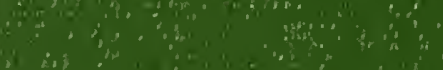

4 a d o

and

and

a

and

a

-

$3 x^{2}$

and

A

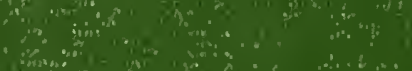

thing

if $\therefore$ a

(4)

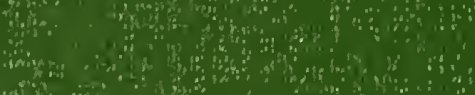

(n)

a d 